\title{
Ethnobotany of medicinal plants in Ada'a District, East Shewa Zone of Oromia Regional State, Ethiopia
}

\author{
Alemayehu Kefalew*, Zemede Asfaw and Ensermu Kelbessa
}

\begin{abstract}
Background: An ethnobotanical study of medicinal plants was conducted in Ada'a District, Eastern Shewa Zone of Oromia Regional State of Ethiopia. The objective of the study was to identify and document medicinal plants and the associated ethnobotanical/ethnomedicinal knowledge of the local people.

Methods: Relevant ethnobotanical data focused on medicinal plants and traditional herbal medicines were collected using guided field walk, semi-structured interview and direct field observation. Informant consensus method and group discussion were conducted for crosschecking and verification of the information. Both descriptive statistics and quantitative ethnobotanical methods were used for data analysis.

Results: We documented 131 species distributed in 109 genera and 54 families based on local claims of medicinal values. Patients who are using traditional drugs and herbalists collect most of these plants from the wild. The leading plant families that encompass large medicinal species were the Lamiaceae (14 species) followed by Asteraceae (13) and Solanaceae (7).

Conclusion: The study reported the existence of a number of medicinal plants, an indication for the presence of plant-based traditional medicinal knowledge transfer that survived through generations. Informants asserted that wild growing medicinal plants are under threat due to increased use pressure coupled with unsuitable harvesting that frequently targets roots and barks for remedy preparations. This calls for urgent and collaborative actions to keep the balance between medicinal plants availability in the wild state and their utilization by the community. Furthermore, the study attempted to prioritize the most efficacious medicinal plants as perceived by the local people for possible pharmacological testing
\end{abstract}

Keywords: Ada'a District, Ethnomedicinal knowledge, Scoring and ranking, Traditional medicinal plants

\section{Background}

Ethnomedicine studies the traditional medical practice and is concerned with the cultural investigation of health, disease and illness and also addresses the healthcare seeking process and healing practices [1-5]. Traditional methods of healing have been beneficial in many countries with or without access to conventional allopathic medicine. Ethiopia, is extremely heterogeneous ecologically [6-8] being a land of topographic diversities [9] and home of multiple ethnolinguistic groups [10]. Moreover, it is known to be a land for the origin of both human kind [11]

\footnotetext{
* Correspondence: alex.aau2001@yahoo.com

Department of Plant Biology and Biodiversity Management, College of Natural Sciences, Addis Ababa University, 3434, Addis Ababa, Ethiopia
}

and plants including crop species [12]. Thus, no wonder that it has diverse indigenous cultures that are carried over from past generations $[9,13]$. One aspect of this indigenous knowledge that began since time immemorial and applied for treating various ailments of human beings and domestic animals is herbal medicine. In agreement with this observation, various magico-religious literature sources $[14,15]$ have noted that Ethiopia has a long history of applying traditional medicines for combating various ailments of humans and livestock.

In Ethiopia, traditional medicine is an integral part of the local culture and is a major public health system $[16,17]$. In addition to its deep cultural rooting, one reason for this is inaccessibility of modern healthcare services. 
According to the Health Sector Development Program (HSDP) of the Ethiopian Ministry of Health, the national standard is given as one hospital for 100, 000 people; one health centre is for 25,000 people and one health post is for 5,000 people. On top of this, the country faces shortage of allopathic health professionals and the ratio of one doctor is for 10, 000 people; one nurse is for 5,000 people, one health extension worker is for 2,500 people [18]. Thus Traditional medicine (TM) is an important means of primary healthcare for achieving the goal, 'Health for all'. The various literature sources available also support this fact where more than $70 \%$ of human and $90 \%$ of livestock population in Ethiopia depend on traditional medicine [19-23]. This tells us that medicinal plants and knowledge of their use provide a vital contribution to human and livestock healthcare throughout Ethiopia.

Similar to elsewhere in Ethiopia, people living in Ada'a District have also traditional practices which they put into effect for generations to take care of themselves and their livestock health. On the other hand, the area has been losing its indigenous flora due to the on-going human and natural causes [24]; and this loss of flora is associated with the missing of important indigenous knowledge on the plants and the traditional medical system. In strengthening this thought, several authors $[25,26]$ noted that intense utilization of forests endangers the revival of the natural vegetation, in general and medicinal plants in particular; thus studying the ethnomedicine (herbal medicine in particular) could be considered as one of the conservation efforts in addition to other benefits in the context of driving many useful experiences for new scientific findings/innovations.

Though we have these facts, literature survey on the ethnobotanical investigation reveals that there is no previously conducted documentation work in any place in the District. Hence, there is a clear need to conduct ethnobotanical study of medicinal plants in the area, to look into and compile relevant information and to document them before the plants become too scarce to capture the knowledge of the indigenous people; and hence this study was initiated.

\section{Methods}

\section{Study area}

This study was conducted is Ada'a District which has a total area of 96, 680 hectares. The area is one of the thirteen Districts in East Shewa Zone of Oromia Regional State of Ethiopia (Figure 1) and is located in the Great Rift

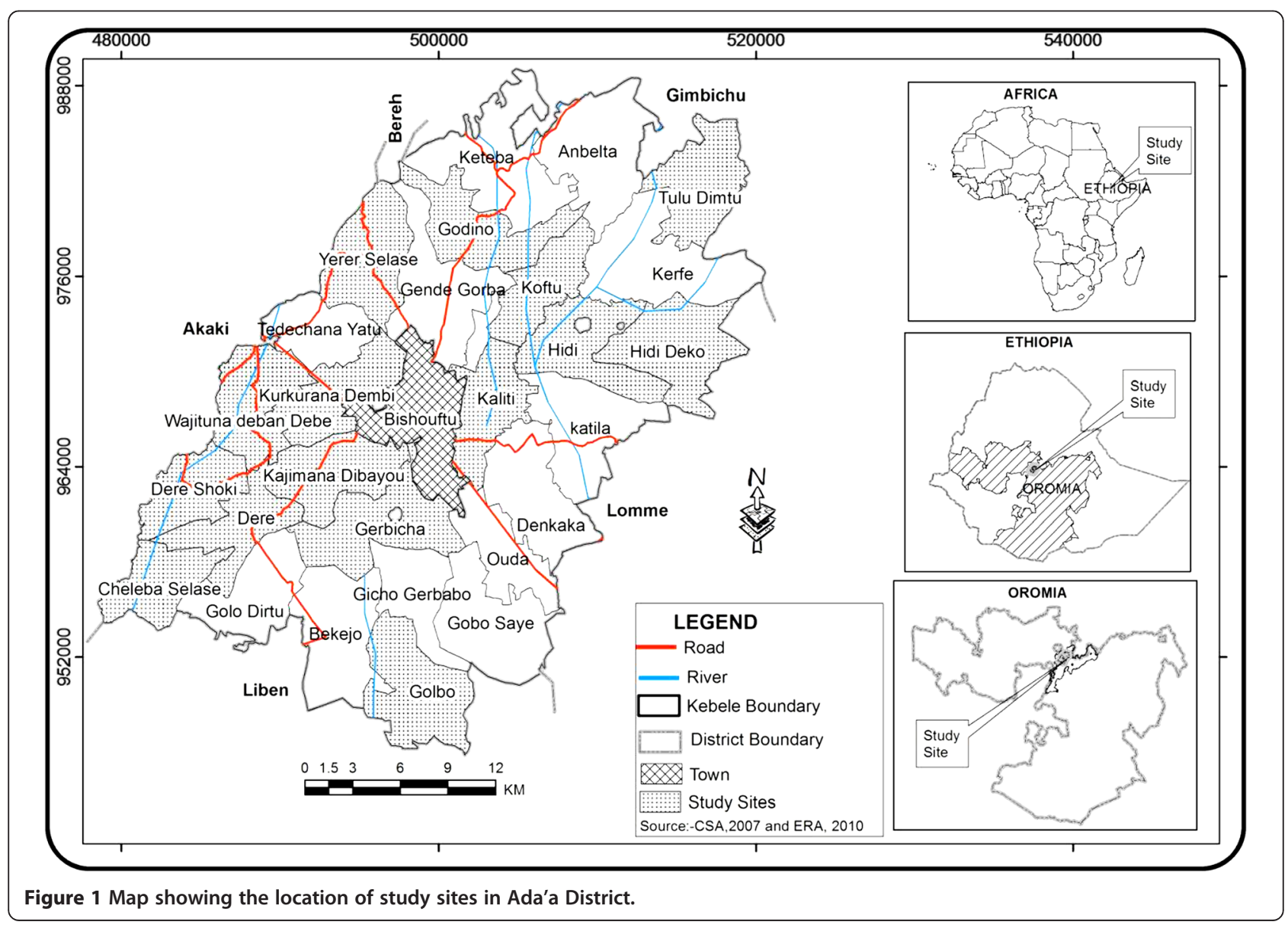


Valley [24]. The relative location of the District is at about $45 \mathrm{~km}$ southeast of Addis Ababa, capital of the country. The District's geographical location as indicated by the Ethiopian Mapping Authority (EMA) satellite image is $08^{\circ} 44^{\prime} \mathrm{E}$ latitude and $38^{\circ} 58^{\prime} \mathrm{N}$ longitude with an altitudinal range of $1540-3100 \mathrm{~m}$ a. s. 1. [24,27].

\section{Sampling design}

Out of the 27 Kebeles (the smallest administrative units) in the District, 15 (Chelebaselase, Dere, Dereshoki, Gerbicha, Godino, Golbo, Hidi, Hidideko, Kajimanadibayou, Kality, Koftu, Kurkuranadembi, Tuludimtu, Wajitunadebandebe, Yererselase) (55. 6\%) were used as sampling kebeles for data collection. The selection of the 15 kebeles was made by purposive sampling based on the availability of traditional healers identified with the assistance of local authorities and elders. Within each kebele localities were identified based on eight habitat criteria (Forest lands, woodlands, grazing lands, fallow land, grasslands, wetlands, cultivated farm land, and home gardens). This procedure gave 140 total localities from which 101 sampling units were selected by taking one locality for each habitat type in each kebele using the lottery method (Table 1). This stratification procedure gave 8 forest land localities, 15 woodlands, 7 wetlands, 11 grasslands, 15 croplands, 15 grazing lands, 15 fallow lands and 15 home gardens that were employed for the collection of relevant data. The selection of localities based on stratification by habitat type was chosen as it is the best representative sample for capturing the medicinal plant and ethnomedicinal knowledge in the District. It is noted that not each kebele was represented by each of the habitat types.

\section{Informant selection}

Informants whose age ranged from 18 to 85 were chosen both purposively and randomly from among those born or have lived there for most of their lives. A total of 105 informants (69 males and 36 females) were used from 15 kebeles (7 informants per kebele). Sixty of the total informants ( 4 per kebele) were randomly selected. This was done in various ways. Some of them were chosen by tossing a coin and using him/her as informant whenever head of the coin was up if $\mathrm{s} /$ he volunteered to participate. Some others were chosen accidentally during random walk made to houses in the selected areas. The other 45 of the total informants ( 3 per kebele) were local experts (key informants) that were selected purposively based on recommendations from the local people, local authorities and development agents (DAs) at each study site.

\section{Ethnobotanical data collection}

For ethical reasons, data were collected in the presence of local administrators and with the consent of each informant for the publication of the research and any accompanying images. Materials used for data collection were mainly plant press for specimen collection, Garmin GPS 72 int'l, digital photo camera and Walkman tape recorder. Ethnobotanical data collection was undertaken during two rounds of field visits during September 2009 to June 2010. The methods employed in the data collection were group discussion, semi-structured interviews, field observation, market survey, scoring and ranking. A checklist of semi-structured questions consisting of issues was prepared in advance. The interviews were done on and around this checklist and some issues were raised depending on responses of informants. During the course of the study, each informant was visited 2-3 times in order to validate the reliability of the ethnobotanical information. The visits were done without planned appointments with the informants. Consequently, the responses of an informant that were not in harmony with each other were considered vague and discarded from the analysis.

Field walk with guides and traditional healer(s) were made during the feasibility study. Group discussions, which were employed in each kebele, were used for cross-checking and verifying the information that has been gathered from individuals by semi-structured interview. The discussions were made with key informants, other traditional healers and the local people sometimes altogether or alone in their categories during field study; and that information was recorded using tape-recorder.

\section{Plant identification}

Voucher specimens of medicinal plants that were reliably reported two times or more during informant visits were collected with the exception of some very common cultivated plants which were identified in the field. These specimens were gathered from the wild, from home gardens and crop fields and preliminary identification of these specimens was made in the field; and they were pressed and taken to the National Herbarium (ETH) of Addis Ababa University (AAU) where they were dried, deep frozen and identified. The identifications were done first using keys of published volumes of the relevant Flora of Ethiopia and Eritrea, and later supported with identification by comparisons with already authenticated specimen in the Herbarium. At last, they were confirmed with the help of taxonomic experts in Addis Ababa University (AAU); and all these voucher specimens were deposited at the National Herbarium.

\section{Data analysis}

Both qualitative and quantitative analytical tools were used for data analysis following the approaches of Martin [1] and Cotton [3]. Percentage frequency method of data analysis was employed to summarize some of the descriptive ethnobotanical data obtained from the interviews on reported 
Table 1 Total number of localities and number of sampling units in Ada'a District

\begin{tabular}{|c|c|c|c|c|c|c|c|c|c|c|c|c|c|c|c|c|c|c|}
\hline \multirow{3}{*}{$\mathrm{S} / \mathrm{N}$} & \multirow{3}{*}{ Kebeles } & \multicolumn{17}{|c|}{ Localities and sampling units for each habitas corresponding to each kebel } \\
\hline & & \multicolumn{2}{|c|}{ Forest land } & \multicolumn{2}{|c|}{ Woodland } & \multicolumn{2}{|c|}{ Wetland } & \multicolumn{2}{|c|}{ Grass land } & \multicolumn{2}{|c|}{ Crop land } & \multicolumn{2}{|c|}{ Grazing land } & \multicolumn{2}{|c|}{ Fallow land } & \multicolumn{2}{|c|}{ Home gardens } & \multirow{2}{*}{$\begin{array}{l}\text { Total number of TNL, } \\
\text { CNL per kebele }\end{array}$} \\
\hline & & TNL & CNL & TNL & CNL & TNL & CNL & TNL & $\mathrm{CNL}$ & TNL & CNL & TNL & CNL & TNL & CNL & TNL & CNL & \\
\hline 1 & Tulu Dimtu & 1 & 1 & 2 & 1 & 1 & 1 & NR & $\mathrm{NR}$ & 2 & 1 & 1 & 1 & 1 & 1 & 2 & 1 & 10,7 \\
\hline 2 & Godino & 1 & 1 & 2 & 1 & $N R$ & NR & 1 & 1 & 2 & 1 & 1 & 1 & 1 & 1 & 1 & 1 & 9,7 \\
\hline 3 & Yererselase & 2 & 1 & 2 & 1 & 1 & 1 & 1 & 1 & 1 & 1 & 2 & 1 & 1 & 1 & 1 & 1 & 12,8 \\
\hline 4 & Koftu & $N R$ & $N R$ & 3 & 1 & 1 & 1 & $N R$ & $\mathrm{NR}$ & 2 & 1 & 1 & 1 & 1 & 1 & 3 & 1 & 11,6 \\
\hline 5 & Hidideko & 1 & 1 & 2 & 1 & $N R$ & $N R$ & 2 & 1 & 1 & 1 & 1 & 1 & 1 & 1 & 2 & 1 & 10,7 \\
\hline 6 & Hidi & NR & NR & 2 & 1 & $N R$ & NR & 1 & 1 & 2 & 1 & 1 & 1 & 1 & 1 & 2 & 1 & 10,6 \\
\hline 7 & Kality & 1 & 1 & 2 & 1 & 1 & 1 & 1 & 1 & 2 & 1 & 1 & 1 & 1 & 1 & 1 & 1 & 10,8 \\
\hline 8 & Kurkuranade & 1 & 1 & 2 & 1 & 1 & 1 & 1 & 1 & 1 & 1 & 2 & 1 & 1 & 1 & 3 & 1 & 12,8 \\
\hline 9 & Dereshoki & NR & NR & 2 & 1 & 1 & 1 & NR & NR & 2 & 1 & 2 & 1 & 1 & 1 & 1 & 1 & 9,6 \\
\hline 10 & Dere & NR & NR & 2 & 1 & $N R$ & NR & 2 & 1 & 1 & 1 & 1 & 1 & 1 & 1 & 1 & 1 & 8,6 \\
\hline 11 & Kajimanadidayou & 1 & 1 & 3 & 1 & NR & NR & NR & NR & 1 & 1 & 1 & 1 & 1 & 1 & 1 & 1 & 8,6 \\
\hline 12 & Gerbicha & $N R$ & NR & 3 & 1 & 1 & 1 & 1 & 1 & 1 & 1 & 1 & 1 & 1 & 1 & 1 & 1 & 9,7 \\
\hline 13 & Wajitunadedandede & NR & NR & 2 & 1 & NR & NR & 1 & 1 & 3 & 1 & 1 & 1 & 2 & 1 & 2 & 1 & 11,6 \\
\hline 14 & Chelebaselase & NR & NR & 1 & 1 & NR & NR & 1 & 1 & 2 & 1 & 1 & 1 & 1 & 1 & 1 & 1 & 7,6 \\
\hline 15 & Golbo & 1 & 1 & 2 & 1 & NR & NR & 1 & 1 & 1 & 1 & 1 & 1 & 1 & 1 & 3 & 1 & 10,7 \\
\hline \multicolumn{2}{|c|}{ Total number of Localities } & 9 & - & 32 & - & 7 & - & 13 & - & 23 & - & 15 & - & 16 & - & 25 & - & 140 \\
\hline \multicolumn{2}{|c|}{ Total number of sampling units } & - & 8 & - & 15 & - & 7 & - & 11 & - & 15 & - & 15 & - & 15 & - & 15 & 101 \\
\hline
\end{tabular}

N.B: TNL-Total number of localities, CNL-Chosen number of locality, NR-Not represented. 
medicinal plants and associated knowledge. Microsoft Excel spread sheet was employed for organizing some ethnobotanical data. Preference ranking was performed to analyse most popular and preferred medicinal plants (MPs), at least in the context of the people who used them against blackleg, which was one of the most frequently reported livestock disease in the area. Direct matrix ranking was done to rank up medicinal plants reported frequently with various ethnobotanical roles.

Informant consensus factor (ICF) was used to find out most trusted healing plants for those disease categories that are claimed to be more common in the district following the approach of Heinrich and co-workers [28] by using the following formula:

$$
\begin{gathered}
I C F=\frac{N_{U C}-N_{S}}{N_{U C}-1} \text { where } \\
N_{U C}=\text { number of use citation (report) in disease category; } \\
N_{S}=\text { number of species used for each citations (report) }
\end{gathered}
$$

Other researchers [29] have also shown that this is a good means of assessing the agreements of informants on the common ailment categories, and thus we used it to test the consensus of the people in the District on curing the disease categories for which the plants were claimed to be effective.

Fidelity level/Species consensus has also been employed to rate the comparative curative capacity of reported traditional medicinal plants (TMP); and it was calculated by applying the formula: $F L=\left(\frac{S_{f}}{T_{f}}\right) \times 100$ where $S_{f}$ refers to frequency of citationsfor a specific ailment;

$T_{f}$ refers to total number of citations of that species. In this analysis, the consensus report of a species for treating a particular disease is seen with the report of that species for treating any given disease in the district $[30,31]$.

\section{Results}

Diversity of medicinal plants (MPs) in the study area

A total of 131species of MPs were gathered that were grouped under 109 genera and 53 families (Table 2). Of these plants, shrubs took the highest proportion (39\%) whereas lianas took the least proportion (Figure 2).

\section{Plant parts used for remedy preparation}

Various plant parts were reported for remedial preparation in the District (Figure 3). Roots were found to be the most familiar plant part for remedy preparations (74 species, 38.34\%) followed by Leaf (65 species, $33.68 \%$ ), fruits (12 species, $6.22 \%$ ) and many other parts (42 species, $32.06 \%$ ).
Table 2 Taxonomic diversity of medicinal plants in Ada'a District

\begin{tabular}{lllll}
\hline Families & $\begin{array}{l}\text { No. of } \\
\text { genera }\end{array}$ & $\begin{array}{l}\text { \% of } \\
\text { genera }\end{array}$ & $\begin{array}{l}\text { No. of } \\
\text { species }\end{array}$ & $\begin{array}{l}\text { \% of } \\
\text { species }\end{array}$ \\
\hline Lamiaceae & 12 & 11.0 & 14 & 10.6 \\
Asteraceae & 11 & 10.1 & 12 & 9.2 \\
Solanaceae & 5 & 4.5 & 7 & 5.3 \\
Euphorbiaceae & 3 & 2.7 & 5 & 3.8 \\
Fabaceae & 3 & 2.7 & 5 & 3.8 \\
Apiaceae & 4 & 3.6 & 4 & 3.1 \\
Other 48 families & 71 & 65.2 & 84 & 64.1 \\
\hline
\end{tabular}

\section{Treated ailments and frequently reported medicinal} plants

The MPs reported from the study area were used to treat both human and animal ailments. Among the documented MPs, 85 (64\%) were those claimed to be used to treat human diseases (Table 3), 19 (15\%) to treat livestock ailments (Table 4) and about 27 (21\%) to treat both livestock and human diseases (Table 5). Among the medicinal plants, Allium sativum, Rubia cordifolia, and Ruta chalepensis were claimed to be the most frequently used medicinal plants as evidenced by the higher number of informant citations (Table 3, Table 4, and Table 5). Details on the mode of preparations and applications of remedies are given in the appendix (Appendix 1).

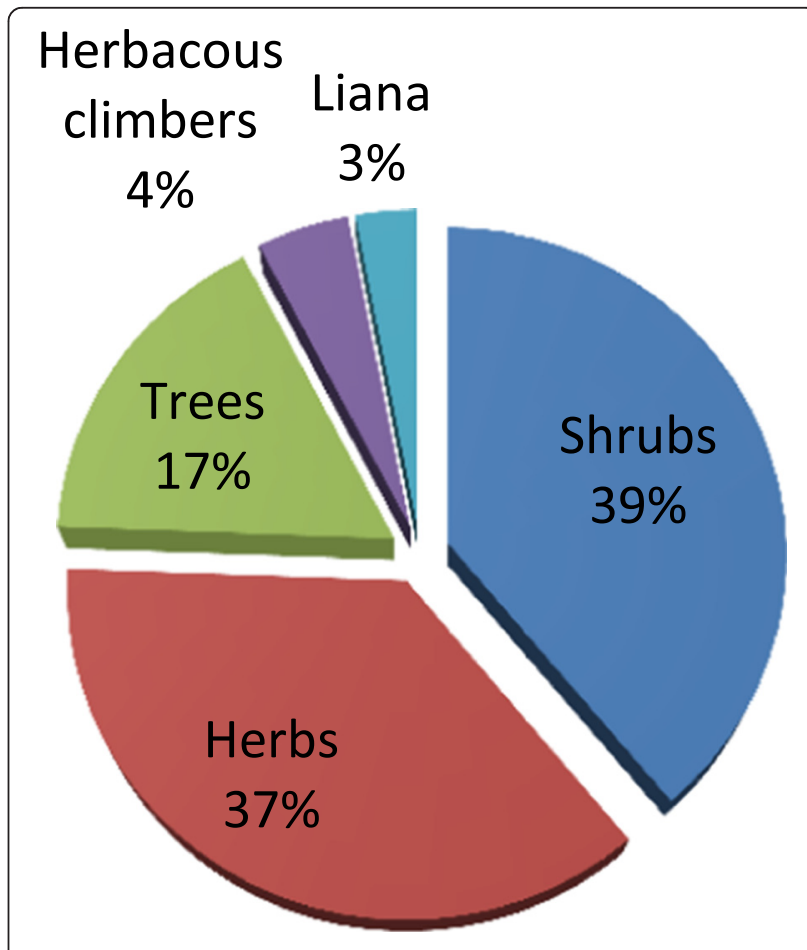

Figure 2 Growth form of medicinal plants in Ada'a District. 


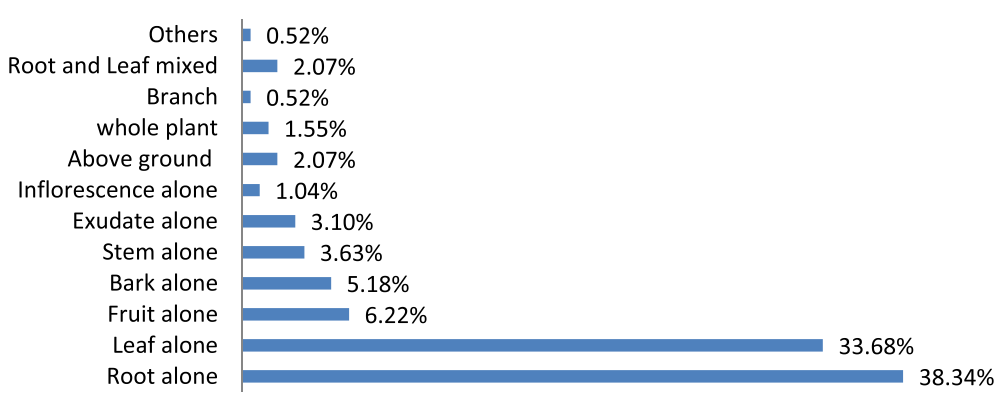

Figure 3 Plant parts used for remedy preparation in Ada'a District.

\section{Preparation of remedies}

Interview carried out with most of the healers of the study area revealed that herbal medications were prepared differently. They often have a preference of mixing two or more MPs so as to avoid or minimize side effect of the remedies. Most of the remedies were prepared in the form of concoction whereas one species (Heteromorpha trifoliata) was served as medicine without processing (Figure 4).

Field observation revealed that healers use debarking, for instance Prunus africana, and uprooting, for example Asparagus africanus, as cases of unfavourable means of herbal collection for remedy preparation (Figure 5).

\section{Routes of application}

The herbal drugs following preparation were reported to be administered in diverse routes (Table 6). The routes and method of applications in the study sites varies with the type of disease treated and the actual sites of the ailments.

\section{Conditions of medicine preparation}

Most commonly, the local people asserted that they prefer the fresh plant part than the dried part for remedy preparation. Among the total MPs, 110 (57.89\%) were used in the fresh form, 77 (40.53\%) were used in the dried form. Only three plants $(2 \%)$ were reported to be used in either form.

\section{Dosages and other related prescriptions}

In this study, provisions of doses vary with age. Such cases were not noted for gender variations. Dose of decoction is measured in various ways (see Figure 6) including tea or coffee cups (small for children, and large-sized for youngsters), JOGE (known to be equivalent to a litre), glass for local liquor (locally called YEAREKE MELEKIYA), local alcoholic beverage cup (TELLA cup), and ANKOLA (a traditional cup made of dried fruit of Lagenaria siceraria). Powdered herbal materials were measured roughly on the palm described as BETAT (i. e., measured by holding the powders between the thump and next (index) finger). Visual observations during herbal preparations showed that palm sanitation of herbalists and container was not considered. Healers also prescribed a particular dose to be taken once, twice or three times per day after carrying out traditional physical examination like looking to patients palm or eye.

\section{Methods of applying treatments (Forms of therapy)}

The documented MPs were used to treat the reported ailments by applying in various ways (Figure 7). Most of the diseases that are inexplicable in the scientific world, like demon possession (GANEN), Evil eye (BUDA), depressions (EJE SEB) were found to be easily treated by healers; and medications were given in the name of WAAQAYOO/REBBY (a local term to mean the almighty God).

\section{Habitat and sources of medicinal plants}

Among the whole MPs, 73 of them (55.72\%) were collected from the wild, 28 (21.37\%) from home gardens (HGs), 20 (15.26\%) from both wild and cropland and 9 species $(6.87 \%)$ from both wild and HGs and the remaining one species, Myrtus communis, was recorded from open market in the District. Those MPs that were obtained from both wild environment (such as forests, grassland, wetlands and so on) and croplands were found as naturally growing plants; and it was observed that they were open for any local people who need to use them. However, those MPs obtained in home gardens were primarily grown for the purpose of foods, as spices, for marketing, as fences, stimulants, and ornaments. In the open market the MPs were usually found in relation to seeds and fruits of spices and herbs.

\section{Most important medicinal plants}

Ranking and scoring method is very helpful to compare and judge widely applicable MPs that have been assured through frequent citations. The results of simple preference ranking by key informants on five most cited MPs against blackleg are shown in Table 7 and direct matrix ranking of five most common multi-purpose MPs are given in Table 8.

\section{ICF and FL values}

Calculation of ICF values showed the most effective medicinal plants against the common illness category of the 
Table 3 List of traditional medicinal plant (MP) species used to treat human ailments in Ada'a District

\begin{tabular}{|c|c|c|c|c|c|c|c|c|c|}
\hline $\mathrm{S} / \mathrm{N}$ & Scientific name & Family & Local name (Afan Oromo/Amaric) & Coll. from & Ha. & UT & TNC & Alt. Range & Coll. No \\
\hline 1 & Acacia seyal Del. & Fabaceae & Wachoo/Wachu & $\mathrm{W} / \mathrm{CL}$ & $\mathrm{T}$ & $\mathrm{Hu}$ & 3 & $1500-2200$ & AK 186 \\
\hline 2 & Achyranthes aspera L. & Amaranthaceae & Derguu/Etse-tekeze & W & $\mathrm{H}$ & $\mathrm{Hu}$ & 20 & $1600-2500$ & AK 003 \\
\hline 3 & Acmella caulirhiza Del. & Asteraceae & Guticha & W & $\mathrm{H}$ & $\mathrm{Hu}$ & 7 & $2100-2500$ & AK 150 \\
\hline 4 & Ageratum houstanianum Mill & Asteraceae & Q/Merzi/Yemerz Medanit & W & $\mathrm{H}$ & $\mathrm{Hu}$ & 5 & $1800-2500$ & AK 265 \\
\hline 5 & Ajuga integrifolia Buch. Ham. & Lamiaceae & Harmmaguusa/Aqorarache & $\mathrm{W} / \mathrm{CL}$ & $\mathrm{H}$ & $\mathrm{Hu}$ & 21 & $1900-2600$ & AK 004 \\
\hline 6 & Allium cepa $\mathrm{L}$. & Alliaceae & Shunkurtiidiimaa/Keyshinkurt & $H G$ & $\mathrm{H}$ & $\mathrm{Hu}$ & 8 & & AK 185 \\
\hline 7 & Allium sativum $\mathrm{L}$. & Alliaceae & Qullubbi adii/Nech shinkurt & $H G$ & $\mathrm{H}$ & $\mathrm{Hu}$ & 32 & & AK 005 \\
\hline 8 & Alternanthera pungens Kunth. & Amaranthaceae & $* * * * *$ & $\mathrm{~W} / \mathrm{CL}$ & $\mathrm{H}$ & $\mathrm{Hu}$ & 3 & $1400-1900$ & AK 228 \\
\hline 9 & Artemisia absinthium L. & Asteraceae & Harritta/Aritii & $H G$ & $\mathrm{H}$ & $\mathrm{Hu}$ & 8 & & AK 184 \\
\hline 10 & Artemisia abyssinica Schtz. Bip. ex Rich & Asteraceae & Tiroo/Chikugne & W & $\mathrm{H}$ & $\mathrm{Hu}$ & 27 & $2400-2700$ & AK 144 \\
\hline 11 & Asparagus africanus Lam. & Asparagaceae & Seriiti/Seriti & W & S & $\mathrm{Hu}$ & 7 & $1500-2700$ & AK 064 \\
\hline 12 & Asparagus racemosus Wild. & Asparagaceae & Seriiti/Seriti & W & S & $\mathrm{Hu}$ & 9 & $1600-2700$ & AK 227 \\
\hline 13 & Asplenium monanthes $\mathrm{L}$. & Aspleniaceae & $* * * * *$ & W & $H(F)$ & $\mathrm{Hu}$ & 2 & $1600-2600$ & AK 009 \\
\hline 14 & Bidens pilosa $\mathrm{L}$. & Asteraceae & Chogogitii/Chogogit & $\mathrm{W} / \mathrm{CL}$ & $\mathrm{H}$ & $\mathrm{Hu}$ & 5 & $1500-2500$ & AK 066 \\
\hline 15 & Caparis tomentosa Lam. & Capparidaceae & Goora/Gumero & W & $\mathrm{CL}$ & $\mathrm{Hu}$ & 9 & $1600-2100$ & AK 243 \\
\hline 16 & Capsicum annuum L. & Solanaceae & Qaara/Qariya & $H G$ & $\mathrm{H}$ & $\mathrm{Hu}$ & 5 & & AK 012 \\
\hline 17 & Carissa spinarum (Vahl.) Forssk. ex Endl. & Apocynaceae & Agamsa/Agam & W & S & $\mathrm{Hu}$ & 5 & $1650-2600$ & AK 180 \\
\hline 18 & Catha edulis (Vahl.) Forssk. ex Endl. & Celastraceae & Caatii/Chat & $H G$ & $\mathrm{~T}$ & $\mathrm{Hu}$ & 3 & & AK 223 \\
\hline 19 & Centella asiatica (L.) Urban. & Apiaceae & $* * * * *$ & W & $\mathrm{H}$ & $\mathrm{Hu}$ & 4 & $1800-2400$ & AK 179 \\
\hline 20 & Citrus aurantifolium (L.) Burn. f. & Rutaceae & Loomii/Lomi & $H G$ & S & $\mathrm{Hu}$ & 5 & & AK 222 \\
\hline 21 & Clausena anisata (Wild.) Benth. & Rutaceae & Ulumaa/Limich & W & $S$ & $\mathrm{Hu}$ & 7 & $2000-2400$ & AK 140 \\
\hline 22 & Clerodendrum myricoides (Hochst) Vatke & Lamiaceae & Maraasisaa/misirich & W & S & $\mathrm{Hu}$ & 4 & $2000-2500$ & AK 221 \\
\hline 23 & Colocasia esculenta (L.) Schott & Araceae & Godaree/Godore & $H G$ & $\mathrm{H}$ & $\mathrm{Hu}$ & 4 & & AK 067 \\
\hline 24 & Croton macrostachyus Del. & Euphorbiaceae & Bakaniisaa/Bisana & W & $\mathrm{T}$ & $\mathrm{Hu}$ & 11 & $1600-2500$ & AK 017 \\
\hline 25 & Cucumis dipsaceus Ehrenb. & Cucurbitaceae & Buqee seexanaa/Yesetan kil & $H G$ & $\mathrm{CL}$ & $\mathrm{Hu}$ & 8 & & AK 068 \\
\hline 26 & Cucumis ficifolius A. Rich. & Cucurbitaceae & Holoo/Yemidir enbuay & W & $\mathrm{CL}$ & $\mathrm{Hu}$ & 14 & $1600-2000$ & AK 219 \\
\hline 27 & Cyathula cylindrica Moq. & Amaranthaceae & Derguu/Yemogne Fikir & W & $\mathrm{H}$ & $\mathrm{Hu}$ & 4 & $1700-2600$ & AK 137 \\
\hline 28 & Cymbopogon citratus & Poaceae & Xajisaara/Tej sar & $\mathrm{HG}$ & $\mathrm{H}$ & $\mathrm{Hu}$ & 4 & & AK 069 \\
\hline 29 & Datura stramonium L. & Solanaceae & Atsefaris/Astenagir & W & $\mathrm{H}$ & $\mathrm{Hu}$ & 5 & $2000-2500$ & AK 217 \\
\hline 30 & Dombeya torrida(J. F. Gmel) Bamps & Sterculiaceae & Daanisa/Wolkefa & W & $\mathrm{T}$ & $\mathrm{Hu}$ & 3 & $2500-2700$ & AK 175 \\
\hline 31 & Dregea schimperi(Decne.) Bullock & Asclepiadaceae & Hida/Yeregna missa & W & $\mathrm{LI}$ & $\mathrm{Hu}$ & 4 & $1900-2400$ & AK 021 \\
\hline 32 & Ekebergia capensis Sparrm. & Meliaceae & Somboo/Sombo & W & $\mathrm{T}$ & $\mathrm{Hu}$ & 6 & $2000-2700$ & AK 022 \\
\hline 33 & Eleusine floccifolia Forssk. & Poaceae & Coqorsa/Akerma & $\mathrm{W} / \mathrm{CL}$ & $\mathrm{H}$ & $\mathrm{Hu}$ & 7 & $2100-2500$ & AK 214 \\
\hline
\end{tabular}


Table 3 List of traditional medicinal plant (MP) species used to treat human ailments in Ada'a District (Continued)

\begin{tabular}{|c|c|c|c|c|c|c|c|c|c|}
\hline 34 & Embelia schimperi Vatke & Myrsinaceae & Hanquu/Enqoqo & W & $S$ & $\mathrm{Hu}$ & 8 & $1800-2700$ & AK 134 \\
\hline 35 & Eucalyptus globulus Labill. & Myrtaceae & Nech bahir zaf & $H G$ & $\mathrm{~T}$ & $\mathrm{Hu}$ & 11 & & AK 212 \\
\hline 36 & Euclea racemosa subsp. schimperi & Ebenaceae & Me'essaa/Dedeho & W & $S$ & $\mathrm{Hu}$ & 5 & $1500-2600$ & AK 173 \\
\hline 37 & Euphorbia abyssinica J. F. Gmel. & Euphorbiaceae & Adamii/Kulkual & HG & $\mathrm{T}$ & $\mathrm{Hu}$ & 6 & & AK 073 \\
\hline 38 & Euphorbia ampliphylla & Euphorbiaceae & Adamii/Kulkual & HG & $\mathrm{T}$ & $\mathrm{Hu}$ & 6 & & AK 025 \\
\hline 39 & Euphorbia tirucallii L. & Euphorbiaceae & Cadaa/Kinchib & HG & S & $\mathrm{Hu}$ & 3 & $1500-2000$ & AK 132 \\
\hline 40 & Ferula communis L. & Apiaceae & Dog & W & $\mathrm{H}$ & $\mathrm{Hu}$ & 6 & $2500-2700$ & AK 074 \\
\hline 41 & Foeniculum vulgare Mill. & Apiaceae & Insilaalee/Ensilal & W & $\mathrm{H}$ & $\mathrm{Hu}$ & 23 & $2000-2600$ & AK 075 \\
\hline 42 & Grewia ferruginea Hochst ex . A . Rich. & Tiliaceae & Dhoqonuu/Lenquata & W & S & $\mathrm{Hu}$ & 4 & $1700-2300$ & AK 209 \\
\hline 43 & Guizotia scabra(Vis) Chiov. & Asteraceae & Adaa/Mech & W & $\mathrm{H}$ & $\mathrm{Hu}$ & 2 & $1700-2400$ & AK 030 \\
\hline 44 & Heteromorpha trifoliata (Wendel.) Eckl. \& Zeyh. & Apiaceae & Demehee/Yejib merkuze & W & S & $\mathrm{Hu}$ & 5 & $2200-2500$ & AK 207 \\
\hline 45 & Hypericum quartinianum A. Rich. & Hypericaceae & Muke fonii & W & S & $\mathrm{Hu}$ & 4 & $2000-2500$ & AK 034 \\
\hline 46 & Impatiens ethiopica Grey-Wilson & Balsaminaceae & Yehenshoshilaa zer & HG & $\mathrm{H}$ & $\mathrm{Hu}$ & 2 & & AK 206 \\
\hline 47 & Impatiens rothii Hook. f. & Balsaminaceae & Buri/Gesherit & W & $\mathrm{H}$ & $\mathrm{Hu}$ & 2 & $2400-2600$ & AK 080 \\
\hline 48 & Impatiens tinctoria subsp. abyssinica & Balsaminaceae & Ensosilla & W & S & $\mathrm{Hu}$ & 2 & $1900-2400$ & AK 035 \\
\hline 49 & Jasminum grandiflorum L. & Oleaceae & Qamaxee/Tembelel & W & S & $\mathrm{Hu}$ & 6 & $1700-2500$ & AK 235 \\
\hline 50 & Juniperus procera Endle & Cupressaceae & Gaatiraa/Yehabesha Tid & W/HG & $\mathrm{T}$ & $\mathrm{Hu}$ & 4 & $2100-2800$ & AK 081 \\
\hline 51 & Lagenaria siceraria (Molina) Standl. & Cucurbitaceae & Buqqee/Kil & HG & $\mathrm{H}$ & $\mathrm{Hu}$ & 3 & & AK 238 \\
\hline 52 & Laggera tomentosa (Sch. Bip. ex A. Rich.) Oliv. \& Hiern & Asteraceae & Keskeso & W & $\mathrm{H}$ & $\mathrm{Hu}$ & 3 & $1700-2500$ & AK 166 \\
\hline 53 & Lantana camara L. & Verbenaceae & Yewof kolo & HG & $\mathrm{LI}$ & $\mathrm{Hu}$ & 2 & & AK 038 \\
\hline 54 & Leucas martinicensis (Jacq. ) R. Br. & Lamiaceae & Bokkoluu adii/Ras kimir & W & S & $\mathrm{Hu}$ & 8 & $1900-2400$ & AK 039 \\
\hline 55 & Lippia adoensis Hochst. ex Walp. & Verbenaceae & Kusaayee/Kese & W/HG & S & $\mathrm{Hu}$ & 3 & $1800-2800$ & AK 084 \\
\hline 56 & Mentha spicata & Lamiaceae & Nana & HG & S & $\mathrm{Hu}$ & 4 & & AK 224 \\
\hline 57 & Myrica salicifolia A. Rich. & Myricaceae & Kataba/Shinet & W & $\mathrm{T}$ & $\mathrm{Hu}$ & 4 & $2200-2800$ & AK 232 \\
\hline 58 & Myrtus communis & Myrtaceae & Adasii/Ades & M & S & $\mathrm{Hu}$ & 6 & & AK 088 \\
\hline 59 & Nicotiana tabacum L. & Solanaceae & Tamboo/Tembaho & HG & $\mathrm{H}$ & $\mathrm{Hu}$ & 3 & & AK 044 \\
\hline 60 & Ocimum basilicum L. & Lamiaceae & Besobilla & HG & $\mathrm{H}$ & $\mathrm{Hu}$ & 5 & & AK 122 \\
\hline 61 & Ocimum gratissimum $\mathrm{L}$. & Lamiaceae & Q/Michii/Mech medanit & W & $\mathrm{H}$ & $\mathrm{Hu}$ & 15 & $1700-2500$ & AK 161 \\
\hline 62 & Ocimum lamiifolium Hochst. ex Benth. & Lamiaceae & Demakessie & W/HG & S & $\mathrm{Hu}$ & 24 & $1600-2600$ & AK 045 \\
\hline 63 & Olea europaea subsp. Cuspidata & Oleaceae & Ejersa/Weyra & W/HG & $\mathrm{T}$ & $\mathrm{Hu}$ & 4 & $1900-2600$ & AK 090 \\
\hline 64 & Olinia rochetiana A. Juss. & Oliniaceae & Dalecho & W & S & $\mathrm{Hu}$ & 6 & $2200-2600$ & AK 245 \\
\hline 65 & Osyris quadripartita Decn. & Santalaceae & Waatoo/Qeret & W & S & $\mathrm{Hu}$ & 3 & $1900-2500$ & AK 160 \\
\hline 66 & Otostegia integrifolia Benth. & Lamiaceae & Tungiitii/Tungit & W & S & $\mathrm{Hu}$ & 12 & $1800-2500$ & AK 047 \\
\hline
\end{tabular}


Table 3 List of traditional medicinal plant (MP) species used to treat human ailments in Ada'a District (Continued)

\begin{tabular}{|c|c|c|c|c|c|c|c|c|c|}
\hline 67 & Plantago major L. & Plantaginaceae & Qorxobbii/Yekura wesife & W & $\mathrm{H}$ & $\mathrm{Hu}$ & 6 & $2000-2500$ & AK 120 \\
\hline 68 & Premna schimperi Engl. & Lamiaceae & Urgessa/Chchoho & W & S & $\mathrm{Hu}$ & 4 & $2000-2500$ & AK 051 \\
\hline 69 & Prunus persica (L.) Batsch & Rosaceae & Kokkii/Kok & $H G$ & S & $\mathrm{Hu}$ & 2 & & AK 119 \\
\hline 70 & Pterolobium stellatum (Forssk.) Brenan & Fabaceae & Harengeemmaa/Kontir & W & S & $\mathrm{Hu}$ & 5 & $1800-2400$ & AK 098 \\
\hline 71 & Ricinus communis $\mathrm{L}$. & Euphorbiaceae & Qoboo/Gulo & $\mathrm{HG}$ & $\mathrm{T}$ & $\mathrm{Hu}$ & 6 & & AK 118 \\
\hline 72 & Rosmarinus officinalis $\mathrm{L}$. & Lamiaceae & Siga metsebesha & $H G$ & S & $\mathrm{Hu}$ & 13 & & AK 055 \\
\hline 73 & Rumex nervosus Vahl & Polygonaceae & Dhangaggoo/Embuacho & W & $\mathrm{H}$ & $\mathrm{Hu}$ & 5 & $1800-2600$ & AK 103 \\
\hline 74 & Ruta chalepensis $\mathrm{L}$. & Rutaceae & Xeenaadama/Tsenadam & $\mathrm{HG}$ & $\mathrm{H}$ & $\mathrm{Hu}$ & 29 & & AK 112 \\
\hline 75 & Salix mucronata & Salicaceae & Alaletu/Ahaya & W & $\mathrm{T}$ & $\mathrm{Hu}$ & 6 & $1700-2500$ & AK 153 \\
\hline 76 & Salvia nilotica Jacq. & Lamiaceae & Hulegebe & $\mathrm{W} / \mathrm{CL}$ & $\mathrm{H}$ & $\mathrm{Hu}$ & 3 & $1600-2800$ & AK 104 \\
\hline 77 & Schinus molle L. & Anacardiaceae & Kundoberbere zaf & $H G$ & $\mathrm{~T}$ & $\mathrm{Hu}$ & 3 & & AK 152 \\
\hline 78 & Snowdenia polystachya (Fresen.) Pig. & Poaceae & Muja & W & $\mathrm{H}$ & $\mathrm{Hu}$ & 2 & $1700-2200$ & AK 114 \\
\hline 79 & Solanum marginatum Linn. f. & Solanaceae & Hiddii/Tileku Enbuay & W/CL & $S$ & $\mathrm{Hu}$ & 5 & $1900-2600$ & AK 107 \\
\hline 80 & Thunbergia alata Sims. & Acanthaceae & Hareg & W & $\mathrm{CL}$ & $\mathrm{Hu}$ & 3 & $2200-2500$ & AK 256 \\
\hline 81 & Thymus schimperi Ronniger & Lamiaceae & Xoosanyii/Tosigne & W & $S$ & $\mathrm{Hu}$ & 8 & $2500-2800$ & AK 108 \\
\hline 82 & Urtica simensis Steudel & Urticaceae & Dobii/Sama & W & $\mathrm{H}$ & $\mathrm{Hu}$ & 2 & $2200-2700$ & AK 057 \\
\hline 83 & Verbena officinalis L. & Verbenaceae & Atuch & $\mathrm{W} / \mathrm{CL}$ & $\mathrm{H}$ & $\mathrm{Hu}$ & 9 & $2000-2400$ & AK 109 \\
\hline 84 & Vernonia amygdalina Del. & Asteraceae & Ebicha/Grawa & $H G$ & $\mathrm{~T}$ & $\mathrm{Hu}$ & 13 & & AK 230 \\
\hline 85 & Withania somnifera (L.) Dunal. & Solanaceae & Gizaawaa/Gizawa & W & S & $\mathrm{Hu}$ & 6 & $2400-2600$ & AK 110 \\
\hline 86 & Zehneria scabra L. & Cucurbitaceae & Daaymii/Areg resa & W & $\mathrm{CL}$ & $\mathrm{Hu}$ & 9 & $1900-2500$ & AK 197 \\
\hline
\end{tabular}


Table 4 List of traditional medicinal plant (MP) species used to treat livestock ailments in Ada'a District

\begin{tabular}{|c|c|c|c|c|c|c|c|c|c|}
\hline $\mathrm{S} / \mathrm{N}$ & Scientific Name & Family & Local Name (Oromifa/Amarigna) & Coll. from & Ha. & UT & TNC & Alt.Range & Coll. No \\
\hline 1 & Acacia abyssinica Hochst. ex Benth. & Fabaceae & Laaftoo/Girar & $\mathrm{W} / \mathrm{CL}$ & $\bar{T}$ & $A n$ & 3 & $1500-2500$ & $\overline{A K} 147$ \\
\hline 2 & Acacia albida Del. & Fabaceae & Garbii/Gerbi & W/CL & $\mathrm{T}$ & $A n$ & 5 & $1500-2200$ & AK 001 \\
\hline 3 & Agave sisalana Perrineex Engel. & Agavaceae & Qachaa/Qacha & W/HG & $\mathrm{T}$ & $A n$ & 3 & $1500-2300$ & AK 062 \\
\hline 4 & Bersama abyssinica Fresen. & Melianthaceae & Loliichisa/Azamir & W & $\mathrm{T}$ & $A n$ & 4 & $1700-2600$ & AK 242 \\
\hline 5 & Buddlejia polystachya Fresen. & Buddlejiaceae & Qawissa/Anfar & W/HG & $\mathrm{T}$ & $A n$ & 12 & $2000-2500$ & AK 142 \\
\hline 6 & Dodonaea angustifolia L. f. & Sapindaceae & Etacha/Kitkita & W & S & $A n$ & 3 & $1800-2450$ & AK 216 \\
\hline 7 & Gamphocarpus abyssinicus Decne. & Asclepiadaceae & Rebu Hunda & W & $\mathrm{H}$ & $A n$ & 9 & $2300-2500$ & AK 028 \\
\hline 8 & Hypericum revolutum Vahl & Hypericaceae & Hindhee/Ameja & W & S & $A n$ & 3 & $2000-2500$ & AK 226 \\
\hline 9 & Malva venticillata $\mathrm{L}$. & Malvaceae & Liitii/Lit & W & $\mathrm{H}$ & $A n$ & 2 & $2000-2700$ & AK 040 \\
\hline 10 & Pentas schimperiana (A. Rich.) Vatke & Rubiaceae & Dasie & W & S & $A n$ & 11 & $2100-2600$ & AK 049 \\
\hline 11 & Plantago lanceolata $\mathrm{L}$. & Plantaginaceae & Qorxobbii/Yehaheya Kote & W/CL & $\mathrm{H}$ & $A n$ & 4 & $1900-2500$ & AK 195 \\
\hline 12 & Protea gaguedi J. F. Gmel. & Proteaceae & Dasie & W & S & $A n$ & 11 & $1900-2200$ & AK 241 \\
\hline 13 & Rhus retinorrhoea & Anacardiaceae & Tilem & W & S & $A n$ & 4 & $2000-2700$ & AK 155 \\
\hline 14 & Rhus vulgaris Meikle & Anacardiaceae & Dabobechaa/Kimmo & W & S & $A n$ & 3 & $1900-2800$ & AK 100 \\
\hline 15 & Rosa abyssinica Lindley & Rosaceae & Gora/Kega & W/CL & $S$ & $A n$ & 7 & $2100-2700$ & AK 192 \\
\hline 16 & Sida schimperiana Hochst. ex A. Rich. & Malvaceae & Chefreg & W & $\mathrm{H}$ & An & 4 & $2100-2400$ & AK 191 \\
\hline 17 & Tagetes minuta $\mathrm{L}$. & Asteraceae & Tiro & W & S & $A n$ & 4 & $1600-2300$ & AK 255 \\
\hline 18 & Xanthium strumarium L. & Asteraceae & Yemogne Fikir & W/CL & S & $A n$ & 3 & $1700-2500$ & AK 187 \\
\hline
\end{tabular}

Key: - Coll- Collected; Coll. No - Collection number; Ha-Habit; UT-Used to treat; Alt. Range-Range of Altitudes distribution in meters; W-Wild; CL-Cropland; HG- Home Garden; M-Market; F-Fern; Hu-Human; An-Animal; Bo-Both human and animal; *****- Local name not known; TNC:-Total number of citations

District. Accordingly, seven disease categories that turned out ICF values greater than 0.78 were noted to be the more prevalent health problems in the District (Table 9). The highest plant use citation was recorded for the diseases categorized as gastro-intestinal disorders.

FL is an important means to see for which ailment a particular species is more effective; and accordingly this study found ten plants (Table 10) having higher healing potential $(\mathrm{FL}>55 \%)$ in the context of the local people to treat ailments.

\section{Discussion and conclusion}

Medicinal plants and their occurrences in the study area

The study area yielded 131 MPs used in the traditional medical lore of the people in Ada'a District. Some of the MPs recorded from the study area were also reported by other studies to be used in the medicinal lore of other areas in Ethiopia, and it is summarized in the table below (Table 11).

The finding of such a large number of MP species in this study area is an indication that there has been a continued transfer of plant-based traditional knowledge for generations. Moreover, highest level of shared documentation of this study was observed with [32] sharing 80 herbals in common. This is perhaps because Jeldu [32] and Ada'a district are parts of Shewa highland of Ethiopia and the people belong to the same oromo community known as Tulema where it is highly likely that they have shared norms, cultural beliefs and traditional practices.

The leading plant families that were found to encompass more numbers of medicinal plant species were the Lamiaceae, Asteraceae and Solanaceae in that order. These families are among the top plant families to contain largest medicinal plant species as reported from other parts of Ethiopia [33-35]. This could also be linked with the fact that they are reported to be among the top fifteen plant families in the flora area, Ethiopia and hence expected to contain widely distributed species in the District [36].

With regard to the growth form of medicinal plants, shrubs were found to be the widely used form followed by herbs, trees and climbers. This pattern of growth form was also reflected in other studies conducted elsewhere in Ethiopia [32,33,35,37-40]. The higher frequency of using shrubs and herbs may be due to the fact that the area is part of the wooded grassland ecosystem of the Rift Valley [41] where shrubs and herbs are leading growth forms than trees. This study also showed that most of the medicinal plants are collected from the wild environments (55.72\%) and only one species, Myrtus communis, was recorded from open market place in the District. The wild habitats as a main occurrence site of medicinal plants are also reported in other ethnomedicinal researches conducted elsewhere in Ethiopia [33-35,38-40,42,43]. This shows that the people largely 
Table 5 List of traditional medicinal plant (MP) species used to treat both human and livestock ailments in Ada'a District

\begin{tabular}{|c|c|c|c|c|c|c|c|c|c|}
\hline $\mathrm{S} / \mathrm{N}$ & Scientific name & Family & Local name (Oromifa/Amarigna) & Coll. from & Ha. & UT & TNC & Alt. Range & Coll. No \\
\hline 1 & Aloe macrocarpa Tod. & Aloaceae & Argiisa/Ret & W/CL & H & Bo & 6 & $1850-2150$ & AK 145 \\
\hline 2 & Brucea antidysenterica J. F. Mill. & Simaroubaceae & Qumegno/Abalo & W & S & Bo & 15 & $1900-2700$ & AK 182 \\
\hline 3 & Calpurnia aurea (Ait.) Benth. & Fabaceae & Ceekaa/Digita & W & S & Bo & 6 & $1600-2750$ & AK 225 \\
\hline 4 & Clematis simensis Fresen. & Ranunculaceae & Fiitii/Enderifa & W & LI & Bo & 12 & $1800-2700$ & AK 178 \\
\hline 5 & Cyphostemma adenocaule & Vitaceae & Melas golgul & W & $\mathrm{CL}$ & Bo & 14 & $2000-2450$ & AK 060 \\
\hline 6 & Ficus sur Forssk. & Moraceae & Harbu/Sholla & W & T & Bo & 5 & $1750-2200$ & AK 210 \\
\hline 7 & Fuerstia africana Th. Fries & Lamiaceae & Eje Admek & W & H & Bo & 11 & $1600-2200$ & AK 083 \\
\hline 8 & Hygrophila schulli (Hamilt.) M. R. \& S. M. Almeida & Acanthaceae & $* * * * *$ & W/CL & H & Bo & 3 & $1900-2400$ & AK 079 \\
\hline 9 & Inula confertiflora A. Rich. & Asteraceae & Mognoree/Weynageft & W & S & Bo & 5 & $2200-2600$ & AK 253 \\
\hline 10 & Justicia schimperiana (Hochst. ex Nees) T. Anders & Acanthaceae & Dhumuugaa/Sensel & $\mathrm{HG}$ & S & Bo & 27 & & AK 167 \\
\hline 11 & Kalanchoe petitiana A. Rich & Crassulaceae & Bosoqee/Endahula & W & H & Bo & 24 & $1900-2600$ & AK 257 \\
\hline 12 & Leonotis raineriana Vis. & Lamiaceae & Bokkoluu dimma/Ras kimir & W & S & Bo & 25 & $2400-2700$ & AK 125 \\
\hline 13 & Maesa lanceolata Forssk. & Myrsinaceae & Abbayyii/Kelewa & W & S & Bo & 5 & $2100-2800$ & AK 202 \\
\hline 14 & Melia azedarach L. & Meliaceae & $* * * * *$ & $H G$ & S & Bo & 9 & & AK163 \\
\hline 15 & Myrsine africana $\mathrm{L}$. & Myrsinaceae & Qacama/Kechem & W & S & Bo & 9 & $2200-2600$ & AK 043 \\
\hline 16 & Pavetta abyssinica Fresen. & Rubiaceae & Muke-buniti & W & S & Bo & 5 & $2000-2500$ & AK 027 \\
\hline 17 & Phytolacca dodecandra L' Herit & Phytolaccaceae & Handoode/Endod & W/HG & S & Bo & 19 & $2000-2700$ & AK 095 \\
\hline 18 & Prunus africana (Hook. f. ) Kalms & Rosaceae & Hoomii/Tikur Enchet & W/HG & T & Bo & 14 & $2100-2600$ & AK 097 \\
\hline 19 & Rubia cordifolia L. & Rubiaceae & Enchibir & W & $\mathrm{H}$ & Bo & 31 & $1800-2600$ & AK 111 \\
\hline 20 & Rubus steudneri Schweinf. & Rosaceae & Agogota & W & $\mathrm{H}$ & Bo & 4 & $2500-2800$ & AK 082 \\
\hline 21 & Rumex abyssinicus Jacq. & Polygonaceae & Meqmeqo & W & H & Bo & 9 & $2000-2800$ & AK 154 \\
\hline 22 & Rumex nepalensis Spreng. & Polygonaceae & Shuultii/Tulet & W & $\mathrm{H}$ & Bo & 19 & $1700-2600$ & AK 231 \\
\hline 23 & Solanecio gigas (Vatke.) C. Jeffrey & Asteraceae & Gommana osolee & $H G$ & S & Bo & 7 & & AK 115 \\
\hline 24 & Solanum anguivi Lam. & Solanaceae & HiddiWorabessa/ZerchEnbuay & W/CL & S & Bo & 8 & $1600-2700$ & AK 247 \\
\hline 25 & Solanum incanum L. & Solanaceae & Hiddii/Yehabesha Embuay & W/CL & S & Bo & 6 & $1500-2400$ & AK 151 \\
\hline 26 & Stephania abyssinica (Dillon ex A. Rich.) Walp. & Menispermaceae & Kalaala/Engochit & W & LI & Bo & 26 & $2000-2800$ & AK 189 \\
\hline 27 & Verbascum sinaiticum Benth. & Scrophulariaceae & Guraa Haree/Yahaya joro & W/CL & $\mathrm{H}$ & Bo & 6 & $1900-2600$ & AK 149 \\
\hline
\end{tabular}




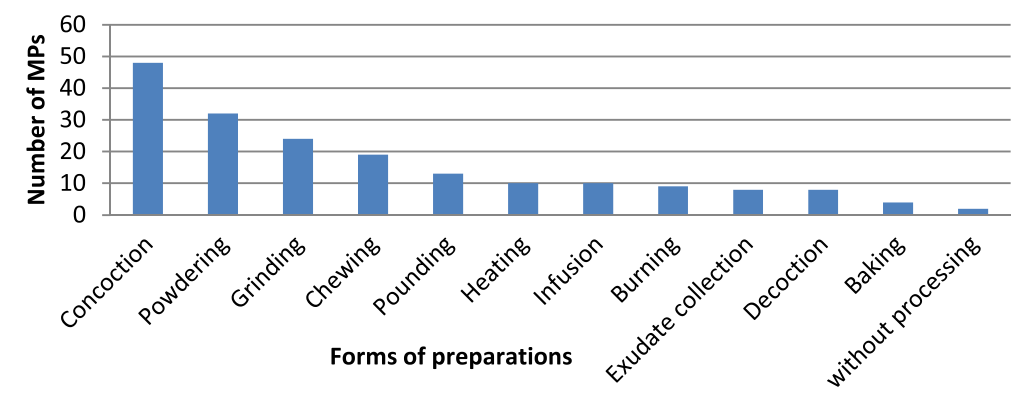

Figure 4 Forms of MPs preparation in Ada'a District.

rely on wild plants; which consequently indicates the existence of higher pressure/threats on the wild medicinal plants. Thus it is a wakeup ring calling for urgent and more collaborative study to maintain the balance between their availability in the wild state and utilization by the community.

\section{Plant part used for remedy preparation, forms of} preparation and route of provision

Among the MPs documented in this study, it is proven that majority of them are used to treat human ailments. This finding aligns with other studies elsewhere in Ethiopia $[9,13,34,38,42,44,45]$ that reported the use of large number of medicinal plants for treating human diseases rather than domestic animals. For treating human and livestock ailments, the local people have acquainted with immense knowledge of remedy preparations.

This study also revealed that mixing of two or more MPs are common practices in remedy preparation. This is in agreement with other findings in Ethiopia $[9,13,38,42]$ where most traditional remedies were prepared by mixing components of two or more plants. Such practices may add the healing potential and minimize the side effect it may inflict on the patient. Similar inference has also been stated in the study outputs of different ethnomedicinal researchers $[9,13,33,34,38,42,44,45]$. On the contrary, this current finding indicates that only few remedies were made from single plant preparations which deviate from the findings of other reports [37,46] where most of the traditional drugs in Bahirdar Zuria and Ada'ar districts

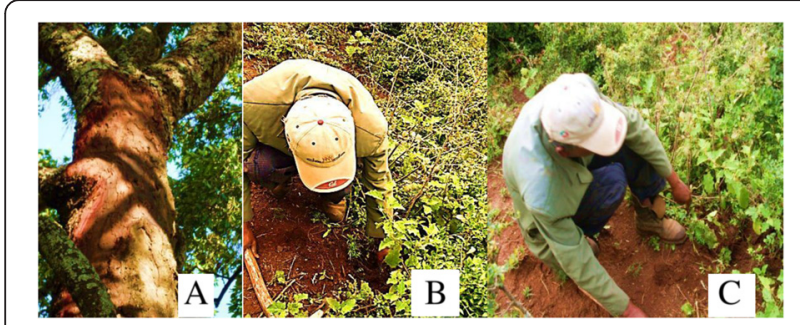

Figure 5 Examples of bad harvesting system, A-debarking Prunus africana \& B and C- uprooting of Asparagus africana for local remedial preparation in Ada'a District. respectively were made from single plant preparations. Most often, the local people of Ada'a district prefer the fresh plant part over the dried part for remedy preparation. Similar findings were reported in other areas of Ethiopia [32-35,37,38,42,44-51] and elsewhere [52-57]. This practice agrees with the scientific fact that the healing potentials of the plant are greater when fresh plant material is used for medicine preparation because the important chemicals are expected to be more and unchanged to other forms as they do when dead and dry resulting in the decline or disappearance of the active principles, usually intermediate metabolites [58].

This study reported the routes and methods of applications in the study sites varied with the type of disease treated and the position where it occurred. The most common route of applications found in this study was oral followed by dermal. This may tell us that the widespread diseases are those that are occurring internally than on the external parts of the body. Similar finding were also noted in other studies [32-35,37-40,42,43,46,50,51,53] among many others

As in most other studies, for example [33,35,43,50], roots were found to be the most familiar plant part for remedy preparations followed by leaves and fruits. Since the root is the most utilized part for remedy preparation, under intensive utilization mode it may attribute to the death of the mother plants and to the loss of the natural vegetation of the area in more severe cases. Moreover,

Table 6 Routes of application of remedies in Ada'a District

\begin{tabular}{lll}
\hline Routes of application & Number of MPs & \% of MPs \\
\hline Oral & 90 & 49.4 \\
Dermal & 70 & 38.4 \\
Nasal & 9 & 4.9 \\
Auricular & 6 & 3.2 \\
Dental & 4 & 2.1 \\
Ocular & 3 & 1.6 \\
Nasal \& auricular & 2 & 1.1 \\
Vaginal & 1 & 0.5 \\
\hline
\end{tabular}




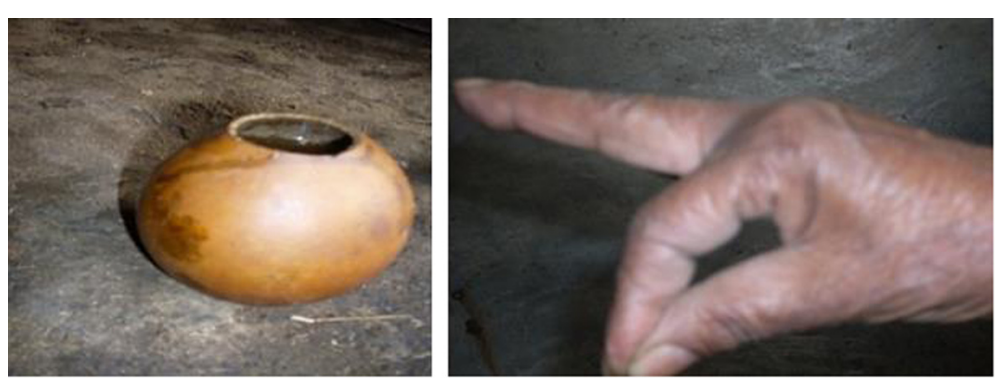

Figure 6 Some ways for measuring doses of herbal medicine in the district (Left ANKOLA, Right BETAT).

this current finding also noted that the total above ground part $(2.1 \%)$ and the whole plant $(1.6 \%)$ are also parts of MPs used for remedy preparation. For example, the entire above ground part of Eleusine floccifolia was used to treat snake bite. Moreover, above ground part of Foeniculum vulgare was reported to treat urine retention. Powder made from the above ground part of Foeniculum vulgare was reported to treat stomach trouble. Planting whole plant of Heteromorpha trifoliate at the back and front yard of the house by a diviner (METSEHAF GELAC'H) was reported to save them against warding of sorcery and attack by magical thieves (SELABI). The whole plant body of Rumex abyssinicus was reported to treat animal scabies (EKEK). Burning the whole plant of Artemisia abysinica and fumigating with the smoke was reported to treat itching eyes.

\section{Local diagnosis, dosages and other related prescriptions}

For some diseases like stomach trouble, cough, stabbing pain and the likes local people easily diagnose, and treat them using self-prepared conventional medicines. But mostly they visit herbalists for some chronic ailments in a similar manner as reported by Kassa [32]. The also showed that the herbalists in the study area made diagnosis like that of the modern physicians that is accompanied first with case-history taking followed by physical examination. Some physical examination includes looking to the patient's eye, or patient's palm. Then they relate the examinations with their work experience, and infer the type of ailments and prescribe the medicine. This may at times result in wrong conclusion of ailment types and provision of local drugs that are uncalled-for.

In this study area, provision of doses varies with ages and ailment condition of the patient. Dose is not measured with standardized cylinder or balance. For instance, the root of Achyranthes aspera would be cut to parts simultaneously saying 'cut the blood of so, i.e, the name of the patient', and infused with brown tef (Eragostis tef), black malt and Rhamnus prinoides and provided to the patient to drink the infusion for three days to treat $\mathrm{RH}$ case (SHOTELAY); and the dose is measured by local containers (JOG or ANKOLA) and taken per day. A concoction of the root and leaf of Justicia schimperiana ground together with the roots of Prunus persica, Nicotiana tabacum and phytolacca dodecandra is drunk for at least a week to treat rabies. Here one tea cup per day was reported to be enough. Root and fruit of Lagenaria siceraria pounded together and drunk with the first boiled coffee (ABOL BUNA) using coffee cup may be enough to treat impotency (SINFET WOSIB). Leaf of Hygrophila schulli was reported to be powdered and the powder will be held between the thump and next (index) finger and dispersed on the wound to treat wound poisoning. Lack of consistency was also reported elsewhere in Ethiopia [33-35,44,48,49] as a serious weakness in the delivery of traditional herbals.

This study also revealed that palm sanitation of herbalists and container was not considered which could

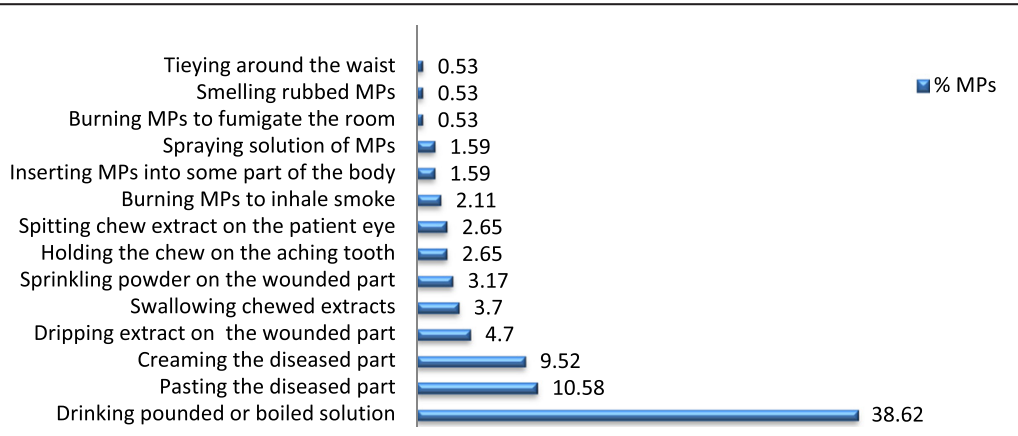

Figure 7 Forms of applying traditional medication/thereapy in Ada'a District. 
Table 7 Results of preference ranking for five MPs against blackleg (Scores in the table shows ranks given to medicinal plant based on their efficacy; thus 5 = most effective, 1 = least preferred)

\begin{tabular}{|c|c|c|c|c|c|c|c|c|c|c|c|c|}
\hline \multirow{2}{*}{$\begin{array}{l}\text { Medicinal plant species } \\
\text { For blackleg }\end{array}$} & \multicolumn{12}{|c|}{ Respondents (R1-R10) } \\
\hline & $R 1$ & $R 2$ & $R 3$ & $R 4$ & $R 5$ & $R 6$ & $R 7$ & $R 8$ & $R 9$ & $R 10$ & Total & Rank \\
\hline Cyphostemma adenocaule & 5 & 4 & 5 & 5 & 2 & 4 & 3 & 5 & 4 & 4 & 41 & $1^{\text {st }}$ \\
\hline Verbascum sinaiticum & 4 & 3 & 2 & 2 & 1 & 1 & 2 & 4 & 3 & 5 & 27 & $4^{\text {th }}$ \\
\hline Prunus africana & 5 & 5 & 4 & 3 & 3 & 5 & 5 & 3 & 2 & 3 & 38 & $2^{\text {nd }}$ \\
\hline Rumex abyssinicus & 2 & 2 & 1 & 1 & 4 & 2 & 1 & 1 & 1 & 1 & 16 & $5^{\text {th }}$ \\
\hline Stephania abyssinica & 3 & 4 & 3 & 4 & 5 & 3 & 4 & 2 & 5 & 2 & 35 & $3^{\text {rd }}$ \\
\hline
\end{tabular}

expose the drugs to contamination and thus may result in some other complications when the treatments are particularly given orally. Healers recommended not only the doses but also prescribe in how long the remedies have to be taken. Some medicines were recommended to be taken only when the patient feels the pain, or twice or three times (equivalent terms in allopathic medicine are TRN, BID and TID, respectively) in a day or days [59] and still others for a week or weeks. Some of these local drugs may be taken in the early morning before getting meal or after; some are taken early morning before urination and still others before beginning any conversation with people. Herbalists also have antidotes that are given if the herbals inflict side effects. Similar findings were reported in other studies $[9,22,45,48]$.

\section{The most important MPs}

Those plant species obtained through ranking by key informants have been placed in the category of priority species for any further action. Cyphostemma adenocaule was reported to be the most widely used plant for treating blackleg. The reasons for showing preferences may be linked with their indigenous knowledge and availability of the plants in close vicinity of the villages in the study area. Among the very common medicinal plants direct matrix showed that Olea europaea subsp. cuspidata was found to be most important in its multiple utility value similar to the findings of Lulekal et al. [38]. From the preference ranking it could be understood that the most favoured species is usually most efficacious at least in the context of the local people and may indicate the occurrence of bioactive chemicals responsible to ward off the causative agents, and it shall be further screened in scientific works for its pharmacological potentials.

\section{Degree of consensus on herbal medicines}

ICF values are important guides to identify more efficacious plants; and through that way they also tell the level of prevalence of diseases in the District. This is because the traditional healing practices normally focused on the most frequent health problems. Accordingly, retained placenta, skeleto-muscular disorders, febril illness and general malaise, circulatory disorders, gastrointestinal disorders, urinary disorders, and gynaecological disorders, which turned up the highest ICF values (1.00-0.78) and hence these are the most prevalent ailment categories in the area. This finding deviates from the results obtained by Kassa [32] who found retained placenta among the least incident diseases while sudden illness and general malaise came among the most prevalent diseases. More prevalence could be linked with economic poverty and poor sanitation problems. Moreover, the dominance of retained placenta may show the lack of awareness and distribution of allopatic contraceptive methods in the District. Those plant species reported to be efficacious for the common health problems of the District are expected to be an input for pharmacologists to check the efficacy in vitro.

FL is an important means to see for which ailment a particular species has more healing power and accordingly those species with high FL are supposed to be

Table 8 Results of direct matrix ranking for five multi-purpose MPs in Ada'a District

\begin{tabular}{|c|c|c|c|c|c|c|c|c|}
\hline \multicolumn{9}{|l|}{ Use category } \\
\hline Plant species & Medicine & Food & Firewood & Charcoal & Construction & Share & Total & Rank \\
\hline Juniperus procera & 4 & 0 & 3 & 1 & 4 & 2 & 14 & $5^{\text {th }}$ \\
\hline Acacia albida & 4 & 0 & 3 & 4 & 3 & 1 & 15 & $4^{\text {th }}$ \\
\hline Croton macrostachyus & 5 & 0 & 2 & 3 & 3 & 4 & 16 & $3^{\text {rd }}$ \\
\hline Olea europaea subsp. & 4 & 2 & 2 & 3 & 3 & 4 & 18 & $1^{s t}$ \\
\hline \multicolumn{9}{|l|}{ Cuspidata } \\
\hline Prunus africana & 4 & 2 & 2 & 3 & 3 & 3 & 17 & $2^{\text {nd }}$ \\
\hline
\end{tabular}

N. B: Number in the table shows average scores of four key informants given to each medicinal plants based on their multipurpose use categories. 
Table 9 Results of Informants consensus factor (ICF) for more prevalent health problems of the District

\begin{tabular}{|c|c|c|c|c|}
\hline $\begin{array}{l}\text { More prevalent } \\
\text { disease category }\end{array}$ & List of plant species used and number of citation in the bracket & $\begin{array}{l}\text { Total no. } \\
\text { of species }\end{array}$ & $\begin{array}{l}\text { Total no. } \\
\text { of citation }\end{array}$ & ICF \\
\hline Retained placenta & Solanecio gigas(7) & 1 & 7 & 1.00 \\
\hline $\begin{array}{l}\text { Skeleto-muscular } \\
\text { disorder }\end{array}$ & Ajuga integerifolia (4), Pterolobium stellatum (5) & 2 & 9 & 0.88 \\
\hline $\begin{array}{l}\text { Febril illness \& General } \\
\text { malaise }\end{array}$ & $\begin{array}{l}\text { Allium sativum (3), Croton macrostachyus (6), Eucalyptus globulus (7), Fuerstia africana (1), } \\
\text { Lantana camara (2), Leonotis raineriana (1), Leucas martinicensis (8), Myrtus communis (3), } \\
\text { Ocimum gratissimum (15), Ocimum lamiifolium (24), Otostegia integrifolia (12) }\end{array}$ & 11 & 82 & 0.87 \\
\hline Circulatory disorder & Allium cepa (6), Nicotiana tabacum (3), Thymus schimperi (8) & 3 & 17 & 0.87 \\
\hline $\begin{array}{l}\text { Gastro-intestinal } \\
\text { disorder }\end{array}$ & $\begin{array}{l}\text { Achyranthes aspera (11), Ajuga integerifolia (8), Allium sativum(5), Aloe macrocarpa (3), Artemisia } \\
\text { abyssinica (12), Asparagus africanus (7), Asparagus racemosus (9), Capsicum annuum (5), Carissa } \\
\text { spinarium (3), Citrus x limon (5), Clerodendrum myricoides (4), Croton macrostachyus (5), } \\
\text { Cucumis ficifolius (14), Cyathula cylindrica (4), Embelia schimperi (8), Eucalyptus globulus (4), } \\
\text { Foeniculum vulgare (5), Grewia ferruginea (4), Lippia adoensis (4), Myrica salicifolia (4), Ruta } \\
\text { chalepensis (29), Vernonia amygdalina (3), Rumex nepalensis (3) }\end{array}$ & 23 & 159 & 0.86 \\
\hline Urine Retention & Foeniculum vulgare (6), Rumex nepalensis (4), Zehneria scabra (3) & 3 & 13 & 0.83 \\
\hline $\begin{array}{l}\text { Gynaecological } \\
\text { disorder }\end{array}$ & Achyranthes aspera (4), Solanum marginatum (3), Stephania abyssinica (3) & 3 & 10 & 0.78 \\
\hline
\end{tabular}

more curative for the respective ailments. Thus, those traditionally used MPs with high FL can be a focus for further pharmacological tests.

\section{Threats of medicinal plants in the study area}

Some of the MPs reported by the local people to be threatened are also included in the IUCN Red lists [60]. Inula confertiflora, which is under the near threatened (NT) category and Otostegia integrifolia, which is under the vulnerable (VU) category of the IUCN Red List are the common ones. Among those in the least concern (LC) category, Solanecio gigas and Lippia adoensis are the MPs recorded from the study area. Other MPs of Ada'a District including Acacia abysinica, Impatiens rothii, Jasminum stans, Laggera tomentosa and Urtica simensis are endemic species [60-63], which are among the common threatened MPs in the study area. Juniperus

Table 10 FL values for some medicinal plants in Ada'a District

\begin{tabular}{lllll}
\hline Healing plants & $\begin{array}{l}\text { Ailments claimed } \\
\text { to be cured }\end{array}$ & Tf & Sf & FL value (\%) \\
\hline Acacia albida & Cattle eye bruise & 5 & 5 & 100 \\
Acmella caulirhiza & Loose tooth & 7 & 7 & 100 \\
Gamphocarpus abyssinicus & Blackleg & 9 & 9 & 100 \\
Kalanchoe petitiana & Swelling & 24 & 24 & 100 \\
Leucas martinicensis & General malaise & 8 & 8 & 100 \\
Ocimum lamiifolium & General malaise & 24 & 24 & 100 \\
Ruta chalepensis & Abdominal pain & 29 & 29 & 100 \\
Leonotis raineriana & Leech & 25 & 15 & 60 \\
Verbena officinalis & Tonsillitis & 9 & 5 & 56 \\
Mysine africana & Taeniasis & 9 & 5 & 55 \\
\hline
\end{tabular}

procera, Olea europaea subsp. cuspidata, Dodonaea angustifolia, Embelia schimperi were reported to be locally threatened MPs in need of conservation efforts even if they are not under IUCN Red Lists.

Table 11 Number of MP species of Ada'a District reported from studies in other parts of Ethiopia

\begin{tabular}{|c|c|c|c|}
\hline Part of Ethiopia & $\begin{array}{l}\text { Number of } \\
\text { MP species }\end{array}$ & $\begin{array}{l}\text { \% of MP } \\
\text { species found } \\
\text { in Ada'a }\end{array}$ & Source \\
\hline Gemad, northern Ethiopia & 18 & 13.7 & {$[47]$} \\
\hline $\begin{array}{l}\text { Kilte Awulaelo, northern } \\
\text { Ethiopia }\end{array}$ & 52 & 39.6 & {$[48]$} \\
\hline $\begin{array}{l}\text { Lake Zway Island, southern } \\
\text { Ethiopia }\end{array}$ & 15 & 11.4 & [44] \\
\hline Wonago, southern Ethiopia & 43 & 32.8 & {$[45]$} \\
\hline Babile, eastern Ethiopia & 9 & 6.8 & [49] \\
\hline $\begin{array}{l}\text { Harla and Dengego,eastern } \\
\text { Ethiopia }\end{array}$ & 23 & 17.5 & [33] \\
\hline Assosa, western Ethiopia & 14 & 10.6 & [50] \\
\hline $\begin{array}{l}\text { Wayu Tuka, western } \\
\text { Ethiopia }\end{array}$ & 33 & 25.2 & [34] \\
\hline $\begin{array}{l}\text { Bahirdar-zuria, Northwestern } \\
\text { Ethiopia }\end{array}$ & 10 & 7.6 & [46] \\
\hline $\begin{array}{l}\text { Zegie Peninsula, } \\
\text { Northwestern Ethiopia }\end{array}$ & 27 & 20.6 & [51] \\
\hline $\begin{array}{l}\text { Ada'ar, north eastern } \\
\text { Ethiopia }\end{array}$ & 5 & 3.8 & {$[37]$} \\
\hline $\begin{array}{l}\text { Sekoru, southwestern } \\
\text { Ethiopia }\end{array}$ & 31 & 23.6 & [42] \\
\hline $\begin{array}{l}\text { Mana Angetu, southeastern } \\
\text { Ethiopia }\end{array}$ & 27 & 20.6 & [38] \\
\hline Jeldu, west shewa & 80 & 61.1 & [32] \\
\hline Ankober, north shewa & 36 & 27.4 & {$[35,43]$} \\
\hline
\end{tabular}


Table 12 Lists of MPs collected from Ada'a District (Detail descriptions on the mode of preparations and applications)

\begin{tabular}{|c|c|c|c|c|}
\hline $\mathrm{S} / \mathrm{N}$ & Scientific name & $\begin{array}{l}\text { Local name } \\
\text { (Oromifa/Amarigna) }\end{array}$ & UT & AT (English/Amaric) \\
\hline 1 & $\begin{array}{l}\text { Acacia abyssinica } \\
\text { Hochst. ex Benth }\end{array}$ & Laaftoo/Girar & An & Horse scabies (Yeferse ebite \\
\hline 2 & Acacia albida Del & Garbii/Gerbi & An & Eye bruise (Bilz) \\
\hline 3 & Acacia seyal Del. & Wachoo/Wachu & $\mathrm{Hu}$ & Headache (Ras mitat) \\
\hline \multirow[t]{3}{*}{4} & Achyranthes aspera L. & Derguu/Etse-tekeze & $\mathrm{Hu}$ & $\begin{array}{l}\text { Stomach trouble } \\
\text { (Yehod hemem) }\end{array}$ \\
\hline & & & $\mathrm{Hu}$ & $\begin{array}{l}\text { Abdominal pain in womar } \\
\text { after birth (Kurtet) }\end{array}$ \\
\hline & & & $\mathrm{Hu}$ & RH case (Shotelay) \\
\hline
\end{tabular}

PU MPA

IC FP MT RA CP

Root and bark grounded together and wash the animal with 3 G $\quad$ W $\quad$ Ex. D the solution

Ba Fresh bark masticated and spitted out on the eye $\quad 5 \quad C \quad S$ Ea F

RF Root and Fruit grounded, boil in water and breathin the $\quad 3$ Co $\quad F u \quad N \quad D$ smoke

RL Powder of root and leaf concocted with root powder of 11 Co $E$ Or. D/F Allium sativum and drunk once.

L Leaf powdered and drink the water solution $\quad 5 \quad \mathrm{P} \quad$ Dr. Or. D

R Root dig out with horn handled knife wearing silver ring, cut 4 If $\quad$ Dr. Or. $F$ it simultaneously saying 'cut the blood of so and so, i. e the name of the patient', infused with brown tef (Eragostis tef), black malt and Rhamnus prinoides and drink the infusion for

three days. A glass is taken per day

$\begin{array}{lll}\text { Acmella caulirhiza Del. } & \text { Guticha } & \mathrm{Hu} \text { Loose tooth } \\ \text { Agave sisalana } & \text { Qachaa/Qacha } & \text { An Tick }\end{array}$

Agave sisalana

An Tick

Ageratum houstanianum Mill Q/Merzi/Yemerz Medanit/

Hu Poisoning (Merzenet)

Ajuga integerifolia Harmmaguusa Hu Stomach trouble

8 Buch. Ham

/Aqorarache/

$\mathrm{Hu}$ Cold (Bired)

$\mathrm{Hu}$ Gout (Rihi)

Hu Hypertension (Dem bizat)

$9 \quad$ Allium cepa L

Shunkurtii diimaa/Key shinkurt/ Hu Poisoning

Allium sativum $L$.

Qullubbi adii

Hu Ascariasi

/Nech shinkurt/

(Wosfat)
$L \quad$ Leaves chewed and placed it between the aching tooth $7 \quad \mathrm{C}$ Ho $\quad \mathrm{T} \quad \mathrm{F}$

$S$ Stem grounded with fruit of Solanum incanum and 3 G Po Ex. F polishing the bitten area

$R \quad$ Root powder is mixed with butter and put on the affected $5 \quad P \quad P a \quad$ Ex. D part

RL Powder of root and leaf mixed with root powder of Allium $8 \quad 8 \quad P \quad E \quad$ Or. D/F sativum and eaten once.

Allium sativum and eaten once.

Leaf boiled with tea and a cup of it is drunken 3 De Dr. Or. F

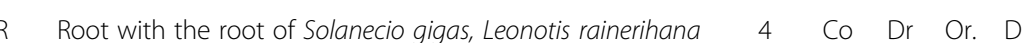
powdered together and mixed with oil from fruit of Olea europaea subsp. cuspidata and Datura stramonium. Concoted them in water and drink the solution for three consecutive days. One cup only once

RL Root and leaf boiled with tea and a cup of the solution is $\quad \begin{array}{lllll}6 & \text { Co } & \text { Dr } & \text { Or. F }\end{array}$ taken in

$\mathrm{R} \quad$ Tie up the root powder with the leaf concoction of Vernonia 7 Co $\quad$ Pa $\quad$ Ex. F amygdalina, Premna schimperi, and root powder of Verbascum sinaiticum

$\mathrm{R}$ Root powder with the root powder of Ajuga integerifolia, Allium sativum, and Rumex nepalensis concocted together and drunk once before breakfast

integerifolia, Allium sativum, and Rumex nepalensis concocted together and drunk once before breakfast 
Table 12 Lists of MPs collected from Ada'a District (Detail descriptions on the mode of preparations and applications) (Continued)

\begin{tabular}{|c|c|c|c|c|c|c|c|c|c|c|c|}
\hline & & & $\mathrm{Hu}$ & Flu (Gunfan) & $\mathrm{RL}$ & $\begin{array}{l}\text { Root and leaf crushed in to pieces, boiled with honey and } \\
\text { take in the liquid in a cup of tea }\end{array}$ & 8 & Co & Dr & Or. & $\bar{F}$ \\
\hline & & & $\mathrm{Hu}$ & Toothache (Tirse himem) & $\mathrm{R}$ & Root crushed, chewed and hold between the aching tooth & 9 & C & Ho & T & $\mathrm{F}$ \\
\hline & & & $\mathrm{Hu}$ & Malaria (Woba) & R & $\begin{array}{l}\text { Root with leaf of Vernonia amaglidina pounded and drunk } \\
\text { the extracted solution }\end{array}$ & 8 & $\mathrm{Pu}$ & Dr & Or. & $\mathrm{F}$ \\
\hline & Aloe macrocarpa Tod. & Argiisa/Ret & $\mathrm{Hu}$ & Intestinal parasite & L & Leaf chewed and swallow the juice & 3 & C & Sw & Or. & $\mathrm{F}$ \\
\hline 11 & & & Bo & Swelling (Ebach) & L & Leaf warmed up on a fire and paste on the swelling & 3 & $\mathrm{He}$ & $\mathrm{Pa}$ & Ex. & $\mathrm{F}$ \\
\hline 12 & $\begin{array}{l}\text { Alternanthera pungens } \\
\text { Kunth. }\end{array}$ & $* * * *$ & $\mathrm{Hu}$ & Sudden illness (Dingetegna) & $\mathrm{R}$ & $\begin{array}{l}\text { Fresh root boiled together with Ocimum gratissimum leaf } \\
\text { and cup of the extract given to drink }\end{array}$ & 3 & Co & Dr & Or. & $\mathrm{F}$ \\
\hline \multirow[t]{4}{*}{13} & Artemisia absinthium L. & Harritta/Aritii & $\mathrm{Hu}$ & Sour throat & $R L$ & $\begin{array}{l}\text { Both root and leaf grounded together with root powder of } \\
\text { Verbena officinalis and the solution sipped in }\end{array}$ & 8 & G & Sw & N & $\mathrm{F}$ \\
\hline & Artemisia abyssinica & Tiroo/Chikugne & $\mathrm{Hu}$ & Whooping Cough (Tektik) & L & $\begin{array}{l}\text { Grounded leaf boiled with the leaf powder of Ruta } \\
\text { chalepensis, honey or butter and taken once a day orally }\end{array}$ & 6 & Co & Dr & Or. & $\mathrm{D}$ \\
\hline & & & $\mathrm{Hu}$ & Stomach trouble & $\mathrm{Br}$ & $\begin{array}{l}\text { Branches together with leaves of Ajuga integerifolia boiled } \\
\text { with butter and eaten together with bread }\end{array}$ & 12 & Co & E & Or. & $\mathrm{F}$ \\
\hline & & & $\mathrm{Hu}$ & Eye itching (Ayenen masakek) & WP & Burn the whole plant and fumigate with the smoke & 9 & $\mathrm{Bu}$ & $\mathrm{Fu}$ & Ex. & $\mathrm{D}$ \\
\hline 15 & Asparagus africanus Lam. & Seriiti/Seriti & $\mathrm{Hu}$ & Amobiasis (Ameba) & $\mathrm{R}$ & $\begin{array}{l}\text { Root powder mixed with honey and butter and eaten for } \\
\text { three consecutive days before breakfast }\end{array}$ & 7 & P & E & Or. & $\mathrm{D}$ \\
\hline 16 & Asparagus racemosus Wild. & Seriiti/Seriti & $\mathrm{Hu}$ & Amobiasis & R & $\begin{array}{l}\text { Root powder mixed with honey and butter and eaten for } \\
\text { three consecutive days before breakfast }\end{array}$ & 9 & P & E & Or. & $\mathrm{D}$ \\
\hline 17 & Asplenium monanthes $L$. & $* * * *$ & $\mathrm{Hu}$ & $\begin{array}{l}\text { Woumb itching (Mehatsenen } \\
\text { masakek) }\end{array}$ & $\mathrm{R}$ & $\begin{array}{l}\text { Root crushed, boiled and wash the itching part with the } \\
\text { decoction }\end{array}$ & 2 & De & W & Ex. & $\mathrm{F}$ \\
\hline 18 & Bersama abyssinica Fresen. & Loliichisa/Azamir & An & Horse Scabies (Bech'h) & $\mathrm{Ba}$ & $\begin{array}{l}\text { Concoction of the bark with root and fruit of Capparis } \\
\text { tomentosa is prepared. Then half of the concoction is given } \\
\text { to drink, and the remaining half is for polish affected areas } \\
\text { after washing }\end{array}$ & 4 & Co & $\begin{array}{l}\text { W } \\
\text { Dr }\end{array}$ & Ex & $\mathrm{F}$ \\
\hline \multirow[t]{2}{*}{19} & Bidens pilosa L. & Chogogitii/Chogogit & $\mathrm{Hu}$ & Devil sickness (Lekefet) & R & $\begin{array}{l}\text { Root with root and leaf of Zehneria scabra boiled and } \\
\text { fumigate the smoke }\end{array}$ & 5 & Co & $\mathrm{Fu}$ & Ex & $\mathrm{F}$ \\
\hline & Brucea antidysenterica & Qumegno/Abalo & $\mathrm{Hu}$ & Evil eye (Buda) & $\mathrm{R}$ & Root powder burns in a fire and inhales the smoke & 9 & $\mathrm{Bu}$ & $\mathrm{Fu}$ & $\mathrm{N}$ & $\mathrm{D}$ \\
\hline 20 & J.F. Mill & & An & Colic (yehod hemem) & L & Leaf grounded and the water solution given to the cattle & 6 & G & Dr & Or. & $\mathrm{F}$ \\
\hline \multirow[t]{2}{*}{21} & Buddlejia polystachya Fresen. & Qawissa/Anfar & An & Leech (Alekit) & $\mathrm{Fl}$ & $\begin{array}{l}\text { Inflorescence with the leaf of Phytolacca dodecandra is given } \\
\text { in nose and ear to expel the parasite }\end{array}$ & 12 & Co & dr. & $\mathrm{NE}$ & \\
\hline & Calpurnia aurea (Ait.) & Ceekaa/Digita & $\mathrm{Hu}$ & Scabies & L & Leaf boiled with leaf of Solanecio gigas and stephania & 3 & Co & Po & Ex. & $\mathrm{F}$ \\
\hline \multirow[t]{2}{*}{22} & Benth. & & & (Ekek) & & abyssinica and drink cup of concoction twice a day. & & & & & \\
\hline & & & An & Pubic hair louse (Qemanjer) & L & $\begin{array}{l}\text { Grounding the leaf and wash the infected skin with the } \\
\text { solution }\end{array}$ & 3 & G & W & Ex. & $\mathrm{F}$ \\
\hline 23 & Caparis tomentosa Lam. & Goora/Gumero & $\mathrm{Hu}$ & Wound (Kusil) & R & $\begin{array}{l}\text { Root powder mixed with latex of Euphorbia tirucallii and } \\
\text { pasted on the wound }\end{array}$ & 9 & $P$ & $\mathrm{~Pa}$ & Ex. & $\mathrm{E}$ \\
\hline
\end{tabular}


Table 12 Lists of MPs collected from Ada'a District (Detail descriptions on the mode of preparations and applications) (Continued)

\begin{tabular}{|c|c|c|c|c|c|c|c|c|c|c|c|}
\hline \multirow[t]{2}{*}{24} & Capsicum annuum L. & Qaara/Qariya & $\mathrm{Hu}$ & Amoebiasis & $\mathrm{Fr}$ & $\begin{array}{l}\text { Fruit dried, powdered and eaten with bread baked of Zea } \\
\text { mays }\end{array}$ & 5 & $\mathrm{Ba}$ & E & Or. & D \\
\hline & Carissa spinarium & Carissa spinarium & $\mathrm{Hu}$ & Intestinal worms & $\mathrm{R}$ & Root grounded, dissolve in water and drunk & 3 & G & Dr & Or. & $\mathrm{D}$ \\
\hline 25 & (Vahl.) Forssk. ex Endl. & & $\mathrm{Hu}$ & Evil eyes & $\mathrm{R}$ & $\begin{array}{l}\text { Root powdered and dispersed on fires to fumigate the } \\
\text { smoke }\end{array}$ & 2 & $\mathrm{Bu}$ & $\mathrm{Fu}$ & Ex. & D \\
\hline 26 & $\begin{array}{l}\text { Catha edulis (Vahl.) Forssk. } \\
\text { ex Endl. }\end{array}$ & Caatii/Chat & $\mathrm{Hu}$ & Ear infection & $L$ & $\begin{array}{l}\text { Leaf boiled with the leaf of Croton macrostachyus and very } \\
\text { small juice applied once daily }\end{array}$ & 3 & Co & $d r$. & Ear & $\mathrm{F}$ \\
\hline 27 & Centella asiatica (L.) Urban. & $* * * * *$ & $\mathrm{Hu}$ & Bleeding & $\mathrm{R}$ & Root powdered and paste it on the bleeding part & 4 & $P$ & $\mathrm{~Pa}$ & Ex. & D \\
\hline 28 & $\begin{array}{l}\text { Citrus aurantifolium (L.) } \\
\text { Burn. f. }\end{array}$ & Loomii/Lomi & $\mathrm{Hu}$ & Abdominal pain (Kurtet) & $\mathrm{Fr}$ & Fruit pounded and sip the extracted liquid after meal. & 5 & $\mathrm{Pu}$ & Dr & Or. & $\mathrm{F}$ \\
\hline 29 & $\begin{array}{l}\text { Clausena anisata (Wild.) } \\
\text { Benth. }\end{array}$ & Ulumaa/Limich & $\mathrm{Hu}$ & toothache & RS & $\begin{array}{l}\text { Cutting root or stem, chew, place and hold on the aching } \\
\text { tooth }\end{array}$ & 7 & C & Ho & Or. & $\mathrm{F}$ \\
\hline & Clematis simensis & Fiitii/Enderifa & Bo & Wound & $L$ & Leaf powdered and carefully sprinkled on the wound. & 4 & $P$ & Sp & Ex. & $\mathrm{F}$ \\
\hline \multirow[t]{3}{*}{30} & Fresen. & & & & & It irritates if dropped on different area & & & & & \\
\hline & & & $\mathrm{Hu}$ & Evil eyes & $\mathrm{R}$ & Root is burned and breathe in the smoke & 4 & $\mathrm{Bu}$ & $\ln$ & N & D \\
\hline & & & $\mathrm{Hu}$ & Wart (Kintarot) & $L$ & $\begin{array}{l}\text { Leaf with leaf of Phytolacca dodecandra powdered together } \\
\text { and sprinkled on the wound }\end{array}$ & 4 & $P$ & Sp & Ex. & $\mathrm{F}$ \\
\hline 31 & $\begin{array}{l}\text { Clerodendrum myricoides } \\
\text { (Hochst) Vatke }\end{array}$ & Maraasisaa/misirich & $\mathrm{Hu}$ & Diaeehae & $\mathrm{R}$ & Root powder solution taken orally & 4 & $P$ & Dr & Or. & $\mathrm{D}$ \\
\hline \multirow[t]{2}{*}{32} & $\begin{array}{l}\text { Colocasia esculenta (L.) } \\
\text { Schott }\end{array}$ & Godaree/Godore & $\mathrm{Hu}$ & Swelling & $L$ & Leaf warmed and applied on the swelling & 4 & $\mathrm{He}$ & $\mathrm{Pa}$ & Ex. & $\mathrm{F}$ \\
\hline & Croton macrostachyus & Bakaniisaa/Bisana & $\mathrm{Hu}$ & Febril illness & $L$ & Leaf pounded, brush lips with it and kept in pocket if & 6 & $\mathrm{Pu}$ & Po & Ex. & $\mathrm{F}$ \\
\hline \multirow[t]{2}{*}{33} & Del. & & & (Megagna) & & any one move out after meal particularly during mid sun & & & & & \\
\hline & & & $\mathrm{Hu}$ & Tinea nigra (Kuakucha) & $L$ & $\begin{array}{l}\text { Polish an infected part with latex squeezed out from } \\
\text { ajuvenile growing leaf }\end{array}$ & 5 & Ex & Po & Ex. & $\mathrm{F}$ \\
\hline 34 & Cucumis dipsaceus Ehrenb. & Buqee seexanaa/Yesetan kil/ & $\mathrm{Hu}$ & Depression (Eje seb) & $L$ & $\begin{array}{l}\text { Leaf cut either Tuesday, Thursday or Saturday early without } \\
\text { having any conversation would be collected, pounded with } \\
\text { leaf of Justicia schimperiana, and fruit of Cucumis ficifolius, } \\
\text { altogether infused for three days and wash the patient with } \\
\text { the infusion for three consecutive days }\end{array}$ & 8 & If & W & Ex. & $\mathrm{F}$ \\
\hline 35 & Cucumis ficifolius A. Rich. & Holoo/Yemidir enbuay & $\mathrm{Hu}$ & Abdominal pain (Kuretet) & $\mathrm{S}$ & Stem chewed and sip the sap & 14 & C & Sw & Or. & $\mathrm{F}$ \\
\hline 36 & Cyathula cylindrica Moq. & Derguu/Yemogn fikir & $\mathrm{Hu}$ & $\begin{array}{l}\text { Stomachache (Yehod } \\
\text { hemem) }\end{array}$ & Se & Seed milled, mixed with water and drunk the solution & 4 & G & Dr & Or. & $\mathrm{D}$ \\
\hline \multirow[t]{2}{*}{37} & Cymbopogon citratus & Xajisaara/Tej sar & $\mathrm{Hu}$ & Cough (Sal) & $L$ & Blow up the leaf and inhale the smoke & 4 & $\mathrm{Bu}$ & $\ln$ & Or. & $\mathrm{F}$ \\
\hline & Cyphostemma & Melas golgul & An & Blackleg & $\mathrm{R}$ & Root pounded and boiled with root powder of & 7 & Co & Dr & Or. & $\mathrm{D}$ \\
\hline \multirow[t]{2}{*}{38} & $\begin{array}{l}\text { adenocaule (Steud. ex. } \\
\text { A. Rich.) Descoings ex }\end{array}$ & & & & & $\begin{array}{l}\text { Verbascum sinaiticum, Rumex abyssinicus and Rumex } \\
\text { nepalensis and drunk to the animal }\end{array}$ & & & & & \\
\hline & Wild \& Drummond & & Bo & Swelling & L & Warm up the leaf and paste on the swelling & 3 & $\mathrm{He}$ & $\mathrm{Pa}$ & Ex. & $\mathrm{F}$ \\
\hline
\end{tabular}


40 Dodonaea angustifolia L. f. Etacha/Kitkita

41 Dombeya torrida (J. F. Gmel) Daanisa/Wolkefa Bamps

42 Dregea schimperi (Decne.) Hida/Yeregna missa Bullock

43 Ekebergia capensis Sparrm. Somboo/Sombo

Eleusine floccifolia Cogorsa/Akerma

44 Forssk.

45 Embelia schimperi Vatke

Hanquu/Enqogo

Eucalyptus globulus

46 Labill.

47 Euclea racemosa Subsp. schimperi

48 Euphorbia abyssinica J. F. Gmel.

49 Euphorbia ampliphylla

50 Euphorbia tirucallii L.

51 Ferula communis $L$. Ficus sur Forssk.

52

\section{Hu Snake bite}

$\mathrm{Hu}$ For Intellegency (Letimret)

An Wound

$\mathrm{Hu}$ Antidot for snake bites

Hu Eczema (Chiffea)

Hu Syphilis (Kitign)

Hu Snake bit

Hu Poisoning

Hu Tape worm (Kosso)

Hu Febril illness

Hu Stomach trouble (Yehod hemem)

$\mathrm{Hu}$ Tonsillitis (Entil siwored)

Hu Haemorrhage

Hu Haemorrhage

Hu Haemorrhage

$\mathrm{Hu}$ cough

$\mathrm{Hu}$ Wart on

hand(Kintarot)

An Swelling

$\mathrm{Hu}$ Urinary Retention

(Shinet leklekelew)
Leaf pounded and creaming all the body to avoid snake

L bite

Fr Fruit powder mixed in a water and drunk the solution. After $5 \quad \mathrm{P} \quad \mathrm{Dr} \quad$ Or. $\quad \mathrm{D}$ drinking $\mathrm{s} /$ he will be kept in a closed room until it is

assimilated with body.

$L \quad$ Leaf is powdered and sprinkle on the wound $\quad 3 \quad P \quad S p \quad E x . \quad D$

$\mathrm{Ba}$ Powder a piece of bark and sprinkle on the bitten part $\quad 3 \quad P \quad S p$ Ex. D

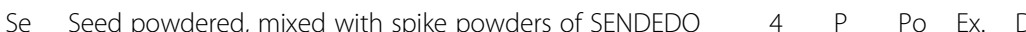
(Pennisetum sp.) and honey, greasing the lesion at least two times daily after washing

Ba Fresh bark infused with root of Cucumis ficifolius for three $\quad 6$ If $\quad$ Dr $\quad$ Or F days and the infusion drunk for a week. Amount day should day shouldn't go beyond the floorboard of a small coffee

Ag Above ground part pounded and paste on the skin $\quad 3 \quad \mathrm{Pu} \quad \mathrm{Pa}$ Ex. F

R Root powder mixed with root powder of Achyranthes aspera $4 \quad$ P $\quad$ Pa $\quad$ Ex. $R$ and fruit of Solanum incanum and paste on the spot

Fr Fruit is powdered, dissolve in water, decant out the decoction and drunk early morning before

Boiling branch and fumigate the patient with the

vapour. After being fumigated the patient cased with blanket and sleep

$\mathrm{Br}$ Branch boiled, fumigate while steaming and sleep wrapping 4 Co $\mathrm{Fu}$ Ex. F all parts of the body

RL Root and leaf together with fruit of Hagenia abyssinica $\quad 5 \quad$ Co $\quad$ Dr Or F boiled together and drink only once in a cup

S White milky sap of the plant carefully dripped on haemorrhage

S White milky sap of the plant carefully tapped on haemorrhage

S White milky sap of the plant carefully tapped on haemorrhage

R Root pulverized, burned and inhale the smoke

La Just two drops of latex from stem is applied on the wart

$L \quad$ Leaf grounded, warmed on fire and tie on the swelling $\quad 2 \quad G \quad P a \quad$ Ex. F

Ag Above ground part is grounded, and the water solution $6 \quad G \quad$ Dr Or. F

drunk. The patient shall not take drinks and/or food for an hour. 
Table 12 Lists of MPs collected from Ada'a District (Detail descriptions on the mode of preparations and applications) (Continued)

\begin{tabular}{|c|c|c|c|c|c|c|c|c|c|c|c|}
\hline & & & $\mathrm{Hu}$ & Stomach trouble & $\mathrm{Ag}$ & $\begin{array}{l}\text { Powdering the above ground part and given the solution } \\
\text { before meal }\end{array}$ & 5 & $P$ & $\operatorname{Dr}$ & Or. & $\mathrm{F}$ \\
\hline & Fuerstia africana Th. & Eje Admek & $\mathrm{Hu}$ & General malaise & L & Leaf grounded and paint the patient body & 10 & G & Po & Ex. & $\mathrm{F}$ \\
\hline \multirow[t]{2}{*}{54} & Fries & & & (Mich) & & & & & & & \\
\hline & & & An & Cattle eye disease & L & $\begin{array}{l}\text { Leaf powdered, mixed with fresh butter and painting the } \\
\text { eye for three consecutive days }\end{array}$ & 13 & & Po & Eye & $\mathrm{D}$ \\
\hline 55 & $\begin{array}{l}\text { Gamphocarpus abyssinicus } \\
\text { Decne. }\end{array}$ & Rebu Hunda & An & Blackleg (Aba gorba) & L & Same as Prunus africana & 9 & Co & Dr & Or. & $\mathrm{D}$ \\
\hline 56 & $\begin{array}{l}\text { Grewia ferruginea Hochst ex } \\
\text {. A. Rich. }\end{array}$ & Dhoqonuu/Lenquata & $\mathrm{Hu}$ & Taeniasis (Kosso) & $\mathrm{Ba}$ & $\begin{array}{l}\text { Fresh bark boiled together with fruit of Hagenia abyssinica, } \\
\text { and the solution drunk }\end{array}$ & 4 & Co & $\operatorname{Dr}$ & Or. & $\mathrm{F}$ \\
\hline 57 & Guizotia scabra (Vis) Chiov. & Adaa/Mech & $\mathrm{Hu}$ & Epilospy (Yemitel beshita) & $\mathrm{R}$ & $\begin{array}{l}\text { Root powdered, boiled with root powders of Ajuga } \\
\text { integerifolia, Foeniculum vulgare and Withania somnifera. One } \\
\text { cup of the concoction taken orally }\end{array}$ & 2 & $\mathrm{Co}$ & Dr & Or. & $\mathrm{D}$ \\
\hline 58 & $\begin{array}{l}\text { Heteromorpha trifoliata } \\
\text { (Wendel. ) Eckl. \& Zeyh. }\end{array}$ & Demehee/Yejib merk uze & $\mathrm{Hu}$ & $\begin{array}{l}\text { Warding of Sorcery Stealing } \\
\text { (Selabi) }\end{array}$ & Wp & $\begin{array}{l}\text { Whole plant planted at the back of the house and on front } \\
\text { yard by a diviner (Metsehaf Gelac'h) }\end{array}$ & 5 & & & - & - \\
\hline 59 & $\begin{array}{l}\text { Hygrophila schulli (Hamilt.) } \\
\text { M. R. \& S. M. Almeida }\end{array}$ & Q/Mearzi & Bo & poisoning & L & Leaf powdered and dispersed on the wound & 3 & $P$ & Sp & Ex. & $\mathrm{D}$ \\
\hline 60 & $\begin{array}{l}\text { Hypericum quartinianum A. } \\
\text { Rich. }\end{array}$ & Muke fonii & $\mathrm{Hu}$ & Jaundice (Yewof beshita) & L & $\begin{array}{l}\text { Leaf with roots of Asparagus } s p \text {. pounded and homogenised } \\
\text { in water and given to the patient orally for three } \\
\text { consecutive days. Half a glass is the limit for a day }\end{array}$ & 4 & Co & Dr & Or. & $\mathrm{D}$ \\
\hline 61 & Hypericum revolutum Vahl & Hindhee/Ameja & An & Eye disease & R & $\begin{array}{l}\text { Root with leaf of Inula confertiflora chewed and spitted on } \\
\text { the eye }\end{array}$ & 3 & C & S & Ey & $\mathrm{F}$ \\
\hline 62 & $\begin{array}{l}\text { Impatiens ethiopica Grey- } \\
\text { Wilson }\end{array}$ & Yehenshoshilaa zer & $\mathrm{Hu}$ & Wound & $\mathrm{R}$ & $\begin{array}{l}\text { Root pounded, warmed in a dish on a fire, and creaming } \\
\text { palms }\end{array}$ & 2 & $\mathrm{Pu}$ & Po & Ex. & $\mathrm{F}$ \\
\hline 63 & Impatiens rothii Hook. f. & Buri/Gesherit & $\mathrm{Hu}$ & Wounds on hand & $\mathrm{R}$ & $\begin{array}{l}\text { Root pounded in to pieces and thoroughly warmed on fire } \\
\text { and firmly hands them for drying the wound }\end{array}$ & 2 & $\mathrm{Pu}$ & Po & Ex & $\mathrm{F}$ \\
\hline 64 & $\begin{array}{l}\text { Impatiens tinctoria A. Rich. } \\
\text { Subsp. abyssinica (Hook. f.) } \\
\text { Grey-Wilson }\end{array}$ & Ensosilla & $\mathrm{Hu}$ & Wound on palm & $\mathrm{R}$ & Root pounded, warmed in a dish on a fire, and oiling palms & 2 & $\mathrm{Pu}$ & Po & Ex. & $\mathrm{F}$ \\
\hline & Inula confertiflora A. & Mognoree/Weynageft & An & Eye disease & R & Root with Hypericum revolutum chewed together and & 3 & C & S & Ey & $\mathrm{F}$ \\
\hline \multirow[t]{4}{*}{65} & Rich & & & & & spitted on the eye & & & & & \\
\hline & & & $\mathrm{B}$ & $\begin{array}{l}\text { Rabies (Yehebid wusha } \\
\text { beshita) }\end{array}$ & R & Root with root of Lagenaria siceraria, Stephania & 2 & Co & Po & Or. & $\mathrm{D}$ \\
\hline & & & & & & $\begin{array}{l}\text { abyssinica, Verbascum sinaiticum and young growing leaves } \\
\text { of Laggera tomentosa, Croton macrostachyus with fruit of } \\
\text { Solanum anguivi all together grounded and boiled, and } \\
\text { drink with milk; or the concoction creamed on meat and } \\
\text { eaten }\end{array}$ & & & & & \\
\hline & Jasminum grandiflorum & Qamaxee/Tembelel & $\mathrm{Hu}$ & Evil eye & $\mathrm{R}$ & Root burned and draw in the smoke & 3 & $\mathrm{Bu}$ & $\ln$ & $\mathrm{N}$ & $\mathrm{D}$ \\
\hline 66 & $\mathrm{~L}$. & & $\mathrm{Hu}$ & Toothache (Yeters himem) & S & Young stem chewed and hold between the aching tooth & 3 & C & Ho & T & $\mathrm{F}$ \\
\hline
\end{tabular}




\section{Table 12 Lists of MPs collected from Ada'a District (Detail descriptions on the mode of preparations and applications) (Continued)}

67 Juniperus procera Endle Gaatiraa/Yehabesha Tid

Justicia schimperiana

Dhumuugaa/Sensel

68 (Hochst. ex Nees) T. Anders
Hu Demon possesesion (Ganen) Fr

Hu Jaundice

(Gubet beshita)

An Sheep diarrhoea

An Blackleg

Hu Rabies

69 Kalanchoe petitiana A. Rich

70 Lagenaria siceraria

Bosoqee/Endahula

Buqqee/Kil

(Molina) Standl

71 Laggera tomentosa (Sch. Bip. ex A. Rich.) Oliv. \& Hiern

72 Lantana camara L.

Keskeso

Yewof kolo

73 Leonotis raineriana Vis.

Bokkoluu dimma/Ras kimir/

74 Leucas martinicensis (Jacq. ) Bokkoluu adii/Ras kimir R. Br.

75 Lippia adoensis Hochst. ex Kusaayee/Kese Walp.

76 Maesa lanceolata Forssk.

77 Malva venticillata L

Melia azedarach L

Abbayyii/Kelewa

Liitii/Lit

Melia

78

79 Mentha spicata

Bo Swelling

Hu Impotency

(Sinfet wosib)

Hu Flu (Gunfan)

Hu General malaise (Mich)

An Leech

Hu General malaise (Mich)

Hu General malaise (Mich)

Bo Swelling

An Swelling

An Chicken diarrhae

An Cattle diarrhae

Hu Taeniasis (Kosso)

Hu Cough and cold
Fruit powder boiled with root of phytolacca dodecandra and 4

fruit powder of Datura stramonium; and wash the patient for

three days

Newly growing leaves of seven different individual

4 Pu $\quad$ Dr Or. F

plants milled on palms and the squeezed liquid added to a

coffee cup. Drink the liquid every morning for a week.

Antidotes recommended is to eat porridge of black teff

(Eragostis tef) and drinking local beer (tella)

L Leaf grounded and mixed with half cup water. The solution $9 \quad G \quad$ Dr Or. F is then drunk

L Leaf powder boiled with root powder of Rubia cordifolia and 8 Co $\operatorname{Dr}$ Or. D bark powder of Prunus africana and given to the cattle

LR Root and leaf boiled together with root of Prunus persica, $\quad 6 \quad$ Co $\quad$ Dr Or. D Nicotiana tabacum and phytolacca dodecandra and drink the solution for at least a week. One tea cup per day is the limit

Hu Kusaayee /Kese
L L Leaf warmed up on a fire and paste on the swelling first boiled coffee (ABOL BUNA)

$\mathrm{L} \quad$ Actively growing leaves collected and pounded together, $3 \mathrm{Pu}$ is $\quad \mathrm{N}$ F wrapped in a piece of cloth and place in noses

L Leaf pounded together with leaf of Ocimum lamiifolium and $2 \quad \mathrm{Pu} \quad \mathrm{Dr} \quad \mathrm{Or}$. F the squeezed out liquid drink with coffee

LF Leaves and flowers grounded and the water solution given $15 \quad \mathrm{G} \quad \mathrm{Dr}$ Or. D to the animal to expel out the parasites

L Leaf pounded together with leaf of Ocimum lamiffolium and $10 \quad \mathrm{Pu} \quad \mathrm{Dr}$ Or. F the squeezed out liquid drink with coffee

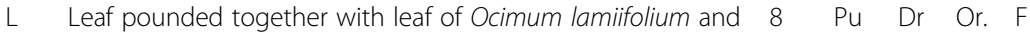
the squeezed out liquid drink with coffee

L Leaf grounded, boiled in water with root powder of $\quad 3 \quad$ Co $\quad$ Dr $\begin{array}{lll}\text { Or. D } & 3\end{array}$ Stephania abyssinica and given to the patient

$L \quad$ Leaf warmed up on a fire and paste on the swelling $\quad 5 \quad \mathrm{He} \quad \mathrm{Pa}$ Ex. F

$L \quad$ Leaf crushed, warmed on fire and tie on the swelling 2 He Pa Ex. F

$L$ Leaf grounded mixed with INJERA and given to the 3 G E Or. D chicken

$L \quad$ Leaf infused in a litter of water; and the infusion is given for 3 If $\operatorname{Dr}$ Or. F the cattle

$L \quad$ Leaf grounded with water and the solution given to the $3 \quad G \quad$ Dr Or. D patient orally

L $\quad$ Leaf boiled with tea and drunk 
Table 12 Lists of MPs collected from Ada'a District (Detail descriptions on the mode of preparations and applications) (Continued)

80 Myrica salicifolia A Rich Kataba/Shinet $\quad$ Hu Ascariasis $\quad$ R Water solution of the root infusion is given orally

Myrsine africana L. Qacama/Kechem Hu Taeniasis

82 Myrtus communis

Adasii/Ades

83 Nicotiana tabacum L

Tamboo/Tembaho

84 Ocimum basilicum L.

Besobilla

85 Ocimum gratissimum L

Q/Michii/Mech medanit

86 Ocimum lamiifolium Hochst. Demakessie ex Benth.

87 Olea europaea L. subsp. cuspidata (Wall. ex G. Don)

Olinia rochetiana A. Dalecho

88 Juss.

89 Osyris quadripartita Decn.

Waatoo/Qeret

90 Otostegia integrifolia Benth. Tungiitii/Tungit

Pavetta abyssinica Muke-buniti

91 Fresen.

92 Pentas schimperiana (A Dasie

Rich.) Vatke

Phytolacca dodecandra Handoode/Endod

93 L' Herit

94 Plantago lanceolata L.
An Worms in donkey

Hu General malaise

An Colic

Hu Exhausion (Lib dikam)

$\mathrm{Hu}$ Flu

Hu General malaise

$\mathrm{Hu}$ General malaise

$\mathrm{Hu}$ QOROQOR

Hu Snake bite

$\mathrm{Hu}$ Toothache

Hu Eczema

Hu Fibril illness (Megagna)

Hu Poison

An Animal diarrhoea

An Eye disease

An BECHE'H

Hu Wart on hand

An Intestinal parasite
Fr Fruit grounded and concocted with powder fruit of Hagenia abyssinica; and the solution drunk

$\mathrm{Fr}$ Decocting fruit with local beer (TELLA) and drink the solution

L Leaf burned and fumigated to the smoke

L L Leaf grounded with fruits of Embelia schimperi and leaf of Vernonia amygdalina and drunk the cattle

Fr Fruit grounded and boiled with root powder of Asparagus 3 Co $\quad$ Dr Or. D solution

$L \quad$ Leaf together with fruit of capsicum annuum and root of Aloe macrocarpa concocted together and drink the solution

Leaf rubbed between palms \& drink the juice

L Leaf pounded with leaf of Lippia adoensis and Fuerstia africana .The squeezed out solution drink with ABOL BUNA (first boiled coffee) and body will be creamed with the remaining leaves

La Latex or oil of any part of the plant is greased on the head 4 Ex $\quad$ Po $\quad$ Ex. F for a week

La Latex from any part of the plant preferably from root mixed with Leaf powder Ficus Vasta and pasted on the wound

$\mathrm{L} \quad$ Young growing leaves cut from three different individual plants, chewed them and hold between the aching tooth

La Latex is mixed with spikes of SINDEDO (Pinnesetum sp.) and 3 Ex Po Ex. F creaming the affected areas

$\mathrm{L} \quad$ Smoke the leaf and fumigate the house for a woman who 12 Bu Fu Ex. F deliver baby

R Root boiled with leaves of Bersama abyssinica and $\quad 2$ Co W Ex. F Rumex abyssinicus and wash the wound with the solution

$L \quad$ Ground the leaf and drunk the solution

S Stem is chewed and spitted on the eye

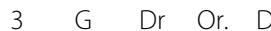

Leaf grounded and wash the area with the solution

10 G W Ex. D Leaf together with Physalis peruviana dried, grounded and 9 Co $\quad$ dr. Ex. D drip a drop or two on the wart 


\section{Table 12 Lists of MPs collected from Ada'a District (Detail descriptions on the mode of preparations and applications) (Continued)}

\begin{tabular}{|c|c|c|c|c|c|c|c|c|c|c|c|}
\hline & & & & & & $\begin{array}{l}\text { Leaf grounded, boiled with fruit of Solanum anguivi and the } \\
\text { concoction mixed with ATELA (by-products of TELLA) and } \\
\text { given to the animal }\end{array}$ & & & & & \\
\hline & Plantago major $L$. & Qorxobbii & $\mathrm{Hu}$ & Poisoning & $\mathrm{R}$ & Root powder is employed to bandage wounds of any & 3 & $P$ & $\mathrm{~Pa}$ & Ex. & $\mathrm{D}$ \\
\hline \multirow[t]{2}{*}{95} & & Mekura wesife/ & & & & kind & & & & & \\
\hline & & & $\mathrm{Hu}$ & Haemorroides & L & Leaf grounded and place it on the wound & 3 & G & $\mathrm{Pa}$ & Ex. & $\mathrm{D}$ \\
\hline 96 & Premna schimperi Engl. & Urgessa/Chchoho & $\mathrm{Hu}$ & Eye disease & L & $\begin{array}{l}\text { Leaf pounded with leaf of Buddlejia polystachya, and } \\
\text { the juice is dripped on the eye }\end{array}$ & 4 & $\mathrm{Pu}$ & dr. & Ey & $\mathrm{F}$ \\
\hline 97 & $\begin{array}{l}\text { Protea gaguedi J. F. } \\
\text { Gmel. }\end{array}$ & Dasie & An & Animal jaundice & L & $\begin{array}{l}\text { Fresh leaf grounded, infused for a day and the solution } \\
\text { given to the animal }\end{array}$ & 11 & If & Dr & Or. & $\mathrm{F}$ \\
\hline \multirow[t]{4}{*}{98} & $\begin{array}{l}\text { Prunus africana (Hook. } \\
\text { f. ) Kalms }\end{array}$ & Hoomii/Tikur Enchet & $\mathrm{Hu}$ & Swelling & $\mathrm{Ba}$ & $\begin{array}{l}\text { Bark dried well, grounded, boiled with water, filtered } \\
\text { and drunk }\end{array}$ & 4 & De & Dr & Or. & $\mathrm{D}$ \\
\hline & & & $\mathrm{Hu}$ & Sudden illness (Dingetegna) & $\mathrm{Ba}$ & Bark dried well, grounded, boiled, filtered and drunk & 6 & De & $\operatorname{Dr}$ & Or. & $\mathrm{D}$ \\
\hline & & & An & Blackleg & $\mathrm{Ba}$ & $\begin{array}{l}\text { Bark powdered, boiled with leaf powder of Gamphocarpus } \\
\text { abyssinicus and the solution given to the animal }\end{array}$ & 2 & Co & $\operatorname{Dr}$ & Or. & $\mathrm{D}$ \\
\hline & & & An & Anthrax (Abasenga) & $\mathrm{Ba}$ & $\begin{array}{l}\text { Bark powdered, mixed with leaf powder of Gamphocarpus } \\
\text { abyssinicus and the solution given to the animal }\end{array}$ & 2 & $\mathrm{P}$ & Dr & Or. & $\mathrm{D}$ \\
\hline 99 & Prunus persica (L.) Batsch & Kokii/Kok & $\mathrm{Hu}$ & Epistaxis (Neser) & $\mathrm{R}$ & Root chewed and band in cloth and place in nose & 2 & $C$ & Is & $\mathrm{N}$ & $\mathrm{F}$ \\
\hline 100 & $\begin{array}{l}\text { Pterolobium stellatum } \\
\text { (Forssk.) Brenan }\end{array}$ & Harengeemmaa/Kontir & $\mathrm{Hu}$ & Rhumantic pain (Kurtimat) & $\mathrm{R}$ & $\begin{array}{l}\text { Root boiled in a cooking dish and fumigating the leg with } \\
\text { vapour. }\end{array}$ & 5 & De & $\mathrm{Fu}$ & Ex. & $\mathrm{F}$ \\
\hline 101 & Rhus retinorrhoea & Tilem & An & Anthrax (Aba senga) & $\mathrm{Ba}$ & $\begin{array}{l}\text { The bark is grounded, boiled with leaf powder of Phytolacca } \\
\text { dodecandra in a cup of water. Drink the solution to the } \\
\text { animal for a week }\end{array}$ & 4 & Co & $\operatorname{Dr}$ & Or. & $\mathrm{F}$ \\
\hline 102 & Rhus vulgaris Meikle & Dabobechaa/Kimmo & An & Diarrhoea & $\mathrm{L}$ & $\begin{array}{l}\text { The leaf together with the leaf of Premna schimperi and } \\
\text { Clerodendrum myricoides is concocted together. The } \\
\text { concoction is given to the cattle }\end{array}$ & 3 & Co & Dr & Or. & $\mathrm{F}$ \\
\hline 103 & Ricinus communis $L$. & Qoboo/Gulo & $\mathrm{Hu}$ & Dandruff (Forofor) & $\mathrm{FL}$ & $\begin{array}{l}\text { Fruit and leaf pounded together and paint the patient's } \\
\text { head skin }\end{array}$ & 6 & $\mathrm{Pu}$ & Po & Ex. & $\mathrm{D}$ \\
\hline 104 & Rosa abyssinica Lindley & Gora/Kega & An & Invoking sprit (Aganent) & L & $\begin{array}{l}\text { Leaf infusion together with leaf powder of Vernonia } \\
\text { amygdalina is prepared and small amount of the solution } \\
\text { placed through nose and the remaining solution is for } \\
\text { painting the body }\end{array}$ & 7 & If & Po & N & $\mathrm{F}$ \\
\hline 105 & Rosmarinus officinalis $L$. & Siga metsebesha & $\mathrm{Hu}$ & Headache & $\mathrm{R}$ & $\begin{array}{l}\text { Root powder mixed powder root of Ocimum gratissimum } \\
\text { and drunk the solution }\end{array}$ & 13 & $P$ & Dr & Or. & $\mathrm{D}$ \\
\hline & Rubia cordifolia L. & Enchiberii/Enchibir & $\mathrm{Hu}$ & Wound & $\mathrm{R}$ & Root grounded and sprinkle the powder on the wound & 13 & P & Sp & Ex. & $\mathrm{D}$ \\
\hline 106 & & & $\mathrm{Hu}$ & Cough & $\mathrm{R}$ & Root is grounded and drink with tea & 6 & G & Dr & Or. & D \\
\hline
\end{tabular}




\section{Table 12 Lists of MPs collected from Ada'a District (Detail descriptions on the mode of preparations and applications) (Continued)}

Root grounded, homogenised and drunk with butter stayed

for 7 years. One glass is the limit for adult and a cup is for

Hu Cough

An Cataract (Bemora yete-shefene R Root chewed with root of Fuerstia africana and spitted on ayen)

Rubus steudneri

07 Schweinf.

Rumex abyssinicus Jaca. 108

Rumex nepalensis

109 Spreng.

110 Rumex nervosus Vahl

111 Ruta chalepensis L.

112 Salix mucronata

113 Salvia nilotica Jaca

114 Schinus molle L.

Sida schimperiana

115 Hochst. ex A. Rich.

116 Snowdenia polystachya (Fresen.) Pig.

117 Solanecio gigas (Vatke.)
Agogota

Hu Stabbing pain

(Wugat)

$\mathrm{Hu}$ Cough

Hu Eye bruise

Meqmeqo

An Blackleg

An Scabies (Ekek)

Shuultii/Tulet

An Colic (Yehod himem)

An Blackleg

Hu Stomach pain (Cheguara)

Hu Stabbing pain (Wugat)

B Urinary retention

Dhangaggoo/Embuacho/

Xeenaadama/Tsenadam/

Alaletu/Ahaya

Hulegebe

Kundoberbere zaf

Chefreg

Hu Delay in drying circumcision

$\mathrm{Hu}$ Abdominal pain

Hu MIKEGNA-SHEREGNA

$\mathrm{Hu}$ Wound

Hu Wound on rectal area

An Rabies

An Preventing bitch birth

Muja

Gommana osolee
Hu Scabies (Ekek)

Bo Retained placenta the cattle's eye

L Leaf powdered, mixed with EMAMESA QEBE (

butter from a cow with same colour calf), and cream it on the area butter from a cow with same colour calf), and cream it on the area

L Leaf with root of Rubia cordifolia and Leaf of Thymus $\quad 2$ Co $\quad$ Dr Or. F schimperi boil together with butter and drink

R Root washed, crushed and boiled with butter. One glass of the solution drunk per day

R Root powdered and given to the cattle with ATELLA (By product of TELLA)

WP Whole plant pounded, mixed with water and wash the animal with it

R Root grounded and drink the water solution

R Root with root of Clematis simensis and Rubia cordifolia boiled and drink the animal

$R$ Root powdered, disperse it in water and drink the solution

Root grounded and drink the solution once in a tea cup

Root with leaf of Foeniculum vulgare boiled together and drink

Root pounded and paste on the penis forehead

Root chewed and ingest the juice

Chewing the leaf and sipping it in

Root powder mixed with butter and applied to wound

Root powder mixed with resin of Euclea racemosa Subsp. schimperi and applied on the wound once a day

R Root dried, powdered, and baked with flour of Tikur teff (Eragostis tef) and given to eat against rabies before an animal bitten by a mud dog

$L \quad$ Leaves infusion mixed with fruit of Solanum incanum is prepared and drunk

R Root boiled with root of Carissa spinarium and wash the animal with the concoction

L Grounding the leaf and drinking the solution. In any 
Table 12 Lists of MPs collected from Ada'a District (Detail descriptions on the mode of preparations and applications) (Continued)

\begin{tabular}{|c|c|c|c|c|c|c|c|c|c|c|c|}
\hline & C. Jeffrey & /Yeshikoko gomen/ & & & & case the dose shall not exceed a cup & & & & & \\
\hline & Solanum anguivi Lam. & Hiddi Worabessa & $\mathrm{Hu}$ & Intelligence & Se & Seed grounded, boiled with leaf of Datura & 3 & Co & Dr & Or. & $\mathrm{F}$ \\
\hline \multirow[t]{4}{*}{118} & & /Zerch Enbuay/ & & & & $\begin{array}{l}\text { stramonium and small amount given to a child to be a fast } \\
\text { learner }\end{array}$ & & & & & \\
\hline & & & $\mathrm{Hu}$ & Danruff & $\mathrm{Fr}$ & $\begin{array}{l}\text { Fruit together with leaf of Acacia albida and Ruta chalepensis } \\
\text { powdered, mixed with Vaseline and paint the head }\end{array}$ & 2 & $P$ & Po & Ex. & $\mathrm{D}$ \\
\hline & & & An & Rabies & $\mathrm{Fr}$ & $\begin{array}{l}\text { Fruit powder baked with brown teff (Eragostis tef) and given } \\
\text { to dog against rabies. This is given to healthier dog not to } \\
\text { be infected with rabies }\end{array}$ & 3 & $\mathrm{Ba}$ & $\mathrm{E}$ & Or. & $\mathrm{D}$ \\
\hline & Solanum incanum $L$. & Hiddii & An & Tick bite & $\mathrm{Fr}$ & Infusion of fresh fruit mixed with kerosene gas and & 2 & If & $\mathrm{Sr}$ & Ex. & $\mathrm{F}$ \\
\hline \multirow[t]{3}{*}{119} & & Nehabesha Embuay/ & & & & spray on the skin of the animal & & & & & \\
\hline & & & An & Horse Scabies & $\mathrm{R}$ & $\begin{array}{l}\text { Pounding the root with carbon (carbon rod of dry cell) and } \\
\text { spraying the water solution on the infected part. }\end{array}$ & 2 & $\mathrm{Pu}$ & $\mathrm{Sr}$ & Ex. & $\mathrm{F}$ \\
\hline & & & $\mathrm{Hu}$ & Wounds & $\mathrm{L} / \mathrm{Fr}$ & $\begin{array}{l}\text { Pounding the fresh leaf and fruit and drip a drop of the } \\
\text { extract on the wound }\end{array}$ & 2 & $\mathrm{Pu}$ & $\mathrm{dr}$ & Ex. & $\mathrm{F}$ \\
\hline 120 & $\begin{array}{l}\text { Solanum marginatum } \\
\text { Linn. f. }\end{array}$ & Hiddii/Tileku Enbuay & $\mathrm{Hu}$ & Long stay menstruation & $\mathrm{R}$ & $\begin{array}{l}\text { Root powdered with roots powder of Achyranthes aspera, } \\
\text { Solanum incanum, Jasminum grandiflorum, wrapped } \\
\text { together, woven three times over head and between legs } \\
\text { and tied around the waist }\end{array}$ & 5 & $P$ & Tw & Ex. & $\mathrm{D}$ \\
\hline & Stephania abyssinica & Kalaala/Engochit & $A n$ & Rabies & $\mathrm{R}$ & Root powder baked with flour of brown tef (Eragostis & 6 & $\mathrm{Ba}$ & $\mathrm{E}$ & Or & $\mathrm{D}$ \\
\hline \multirow[t]{6}{*}{121} & (Dillon ex A. Rich.) & & & & & tef) and small amount given once. & & & & & \\
\hline & Walp. & & An & Blackleg & $\mathrm{R}$ & $\begin{array}{l}\text { Root powders of the plant and Rumex abyssinicus, } \\
\text { Cyphostemma adenocaule, Eucalyptus globules, Allium } \\
\text { sativum, and Solanum incanum mixed together in a litter of } \\
\text { water and drink once }\end{array}$ & 5 & $\mathrm{CO}$ & Dr & Or. & D \\
\hline & & & $\mathrm{Hu}$ & Unwanted pregenancy & $\mathrm{R}$ & $\begin{array}{l}15-20 \mathrm{~cm} \text { fresh root whose upper part chewed inserted to } \\
\text { the womb for aborting unwanted pregnancy }\end{array}$ & 3 & C & Is & V & $\mathrm{F}$ \\
\hline & & & $\mathrm{Hu}$ & Wound & $\mathrm{R}$ & $\begin{array}{l}\text { Either powdered or fresh root boiled with leaf of smilex } \\
\text { aspera and wash the wound }\end{array}$ & 3 & Co & $\mathrm{Pa}$ & Ex. & $\mathrm{D} / \mathrm{F}$ \\
\hline & & & $\mathrm{Hu}$ & Swelling & $\mathrm{R}$ & $\begin{array}{l}\text { Root grounded and dissolved in a cup of water and drink. } \\
\text { The recommended antidotes is to drink ABOL BUNA with no } \\
\text { sugar }\end{array}$ & 5 & $P$ & Dr & Or. & $P$ \\
\hline & & & $\mathrm{Hu}$ & Sudden illness & $\mathrm{R}$ & $\begin{array}{l}\text { Little sized root chewed and only small amount of the } \\
\text { extract swallowed }\end{array}$ & 4 & C & Sw & Or. & $\mathrm{F}$ \\
\hline 122 & Tagetes minuta L. & Tiro & An & KINKIN & $\mathrm{Ag}$ & $\begin{array}{l}\text { Above ground part collected from field and sleep chickens } \\
\text { on it }\end{array}$ & 4 & & & Ex. & $\mathrm{F}$ \\
\hline 123 & Thunbergia alata Sims. & Hareg & $\mathrm{Hu}$ & Cough & $\mathrm{R}$ & Powder of root taken once mixed with honey & 3 & $P$ & E & Or. & $\mathrm{D}$ \\
\hline 124 & Thymus schimperi Ronniger & Xoosanyii/Tosigne & $\mathrm{Hu}$ & Hypertension & $\mathrm{R}$ & Root dried, powdered, and drink with tea & 8 & $P$ & Dr & Or. & $\mathrm{D}$ \\
\hline 125 & Urtica simensis Steudel & Dobii/Sama & $\mathrm{Hu}$ & Gonorrheae (Chebit) & $\mathrm{R}$ & $\begin{array}{l}\text { Infusion of Root is prepared and the genital organ washes } \\
\text { with it once daily. }\end{array}$ & 2 & If & W & Ex. & $\mathrm{F}$ \\
\hline
\end{tabular}


Table 12 Lists of MPs collected from Ada'a District (Detail descriptions on the mode of preparations and applications) (Continued)

\begin{tabular}{|c|c|c|c|c|c|c|c|c|c|c|c|}
\hline & Verbascum sinaiticum & Guraa Haree & $\mathrm{Hu}$ & Nightmare & $\mathrm{R}$ & Root crashed, placed in a fire and fumigating the & 4 & Bu & $\mathrm{Fu}$ & Ex. & $\mathrm{D}$ \\
\hline \multirow[t]{3}{*}{126} & Benth. & Mahaya joro/ & & & & smoke & & & & & \\
\hline & & & An & Blackleg & $\mathrm{R}$ & $\begin{array}{l}\text { Root with Phytolacca dodecandra leaf boiled and the } \\
\text { solution drunk }\end{array}$ & 2 & Co & Dr & Or. & $\mathrm{D}$ \\
\hline & Verbena officinalis L.q & Atuch & $\mathrm{Hu}$ & Cough & $\mathrm{R}$ & Powdered root with the root of Rubia cordifolia & 4 & Co & $\mathrm{E}$ & Or. & $\mathrm{D}$ \\
\hline \multirow[t]{5}{*}{127} & & & & & & cooked with butter; and the concoction taken once daily & & & & & \\
\hline & & & $\mathrm{Hu}$ & Tonsilities (Entil siwored) & $\mathrm{R}$ & Root is chewed and ingesting the juice & 5 & C & Sw & Or. & $\mathrm{F}$ \\
\hline & Vernonia amygdalina & Ebicha/Grawa & $\mathrm{Hu}$ & Warding off sorcery steeling & $L$ & $\begin{array}{l}\text { Infusion of leaf powder kept for a night and will be sprayed } \\
\text { on fences early of the following morning }\end{array}$ & 5 & If & $\mathrm{Sr}$ & & $D$ \\
\hline & & & $\mathrm{Hu}$ & Malaria & $\mathrm{F}$ & Leaf is grounded and the solution taken orally & 5 & G & Dr & Or. & $\mathrm{D}$ \\
\hline & & & $\mathrm{Hu}$ & Abdominal pain & $L$ & Leaf is grounded and the solution taken orally & 3 & G & Dr & Or. & $\mathrm{D}$ \\
\hline 129 & $\begin{array}{l}\text { Withania somnifera (L.) } \\
\text { Dunal. }\end{array}$ & Gizaawaa/Gizawa & $\mathrm{Hu}$ & Daemon possesesion & $\mathrm{R}$ & $\begin{array}{l}\text { Root powder mix with root powder of KEBERICHO (Echinops } \\
\text { kebericho)and smoking in a house who delivered baby }\end{array}$ & 6 & $P$ & $\mathrm{Bu}$ & & $D$ \\
\hline 130 & Xanthium strumarium $L$. & Yemogne Fikir & An & Leech & L & $\begin{array}{l}\text { Leaf juice of Xanthium. strumrium, Clematis simensis, } \\
\text { Calpurnia aurea applied through nose and ear of the animal } \\
\text { to expel the parasite }\end{array}$ & 3 & $\mathrm{Pu}$ & dr. & NE & $\mathrm{F}$ \\
\hline \multirow[t]{2}{*}{131} & Zehneria scabra L. & Daaymii/Areg resa & $\mathrm{Hu}$ & Deformed lips (Megagna) & $\mathrm{R}$ & $\begin{array}{l}\text { Water solution of the grounded root drunk and some paint } \\
\text { near the abnormally deformed lips }\end{array}$ & 6 & G & Dr & Or. & D \\
\hline & & & $\mathrm{Hu}$ & Urinary retention & $\mathrm{R}$ & Root powdered and drink the water solution & 3 & $P$ & Dr & Or. & \\
\hline
\end{tabular}

Key: UT-used to treat ( $\mathrm{An}=$ domestic animal, Hu=Human, Bo=both), AT-Ailments treated, PU-Part used (Ag=above ground part, Ba=bark, Br=branch, $\mathrm{Fl}=$ flowers or inflorescence, $\mathrm{Fr}=$ fruit, $\mathrm{L}=\mathrm{leaf}, \mathrm{L} / \mathrm{fr}=$ leaf and fruit, $\mathrm{La}=$ latex or resin, $\mathrm{Lf}=$ leaf and inflorescence, $\mathrm{R}=$ root, $\mathrm{RB}=$ root and bark, $\mathrm{RF}=$ root and fruit, $\mathrm{RL}=$ root and leaf, $\mathrm{RS}=$ root and stem, $\mathrm{S}=\mathrm{stem}$, Se=Seed, WP=whole plant), IC- total number of informants who cited the MPs for treating the major aliments FP-forms of preparation (Ba=baking, Bu=burning, $\mathrm{C}=$ chewing, $\mathrm{Co}=$ concoction, $\mathrm{De}=$ decoction, $\mathrm{G}=$ grinding, Ex= Exudate collection $\mathrm{He}=$ heating or warming, If=infusion, $\mathrm{P}=$ powdering,

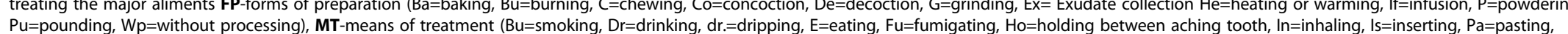

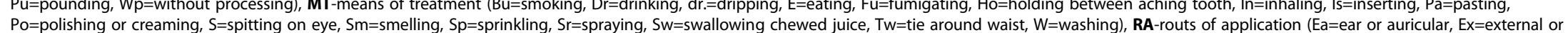
dermal, Ey=Eye or ocular, $\mathrm{N}=$ nasal=NE=nasal and through ear, $\mathrm{Or}=$ oral, $\mathrm{T}=\mathrm{on}$ tooth, $\mathrm{V}=$ =vaginal $\mathrm{CP}$-condition of preparation $\left(\mathrm{D}=\mathrm{dry}, \mathrm{F}=\mathrm{fresh}, \mathrm{DF}=\mathrm{dry}\right.$ or fresh). ${ }^{* * * * *}$ - Local name not known. 


\section{Appendix}

Details on the mode of preparations and applications of remedies are given in the appendix (Table 12).

\section{Competing interests}

The authors declare that they have no competing interests.

\section{Authors' contributions}

All authors have equal contribution; and all authors have read and approved the final manuscript.

\section{Acknowledgments}

We like to thank the local people of Ada'a District for their generosity and kind response to our inquiries for information on the medicinal plants of the area. We also like to thank the Department of Plant Biology and Biodiversity Management (AAU) for the kind response and cooperation in all inquiries during the study period. The technical personnel of the National Herbarium (AAU) are acknowledged for their help in the identification and processing of the voucher specimens. Addisie Yalew deserves gratitude for revising the manuscript and suggest comments. Bamlaku Amentie also deserves gratitude for kindly mapping the study area.

\section{Received: 15 September 2014 Accepted: 23 February 2015}

\section{Published online: 02 April 2015}

\section{References}

1. Martin GJ. Ethnobotany- A Method Manual. London: Chapman and hall; 1995.

2. Balick MJ, Cox PAR. Plants, People and Culture. The Science of Ethnobotany. New York, USA: Scientific American Library; 1996.

3. Cotton CM. Ethnobotany:- Principles and Applications. Chichester, UK: John Wiley and Sons; 1996.

4. WHO. World Health Organization (WHO):- Traditional Medicine, Report by the Secretariat, 56th World Health Assembly, Provisional Agenda item 14.10, A56/18. Geneva; 2003.

5. Asfaw Z, Wondimu T. Introduction to Ethnobiology: People and the Biota. Addis Ababa: Addis Ababa University Press; 2007.

6. Breitenbach FV. The Indigenous Trees of Ethiopia. 2nd ed. Addis Ababa: Ethiopian Forestry Association; 1963.

7. Tesema AB. Useful Trees and Shrubs for Ethiopia, Regional soil Conservation unit (RSCU). Kenya: Nairobi; 1993.

8. Demisse A. Biodiversity Conservation of Medicinal Plants: Problems and Prospects. In: Zewdu M, Demissie A, editors. Conservation and Sustainable use of Medicinal Plants in Ethiopia. Proceedings of the National Workshop on Biodiversity Conservation and Sustainable Use of Medicinal Plants in Ethiopia. Addis Ababa: IBCR; 2001. p. 56-64.

9. Abebe D, Ayehu A. Medicinal Plants and Enigmatic Health Practice of North Ethiopia. Addis Ababa: Berehanina-Selam Printing Enterprise; 1993.

10. Kassu A. Ethnobotanical Survey and the Medicinal Plants of some areas in South and Central Ethiopia. In: Urga K, Assefa A, Guta M, editors. Traditional Medicine in Ethiopia, Proceedings of a National Workshop Held in Addis Ababa, Ethiopia, on June 30-2 July. Addis Ababa, Ethiopia: EHNRI; 2004. p. 81-91.

11. Reed KE. Paleoecological patterns at the Hadar hominin site, Afar Regional state, Ethiopia. J Hum Evol. 2008:54:743-68.

12. Vavilov NI. The origin, variation, immunity and breeding of cultivated plants. Chronica Botanica. 1951:13:1-366.

13. Abate G. Etse Debdabe: Ethiopian Traditional Medicine (Amharic version). Edited by Demissew S: Addis Ababa University; 1989.

14. Kebebew F. The Status and Availability of Oral and Written Knowledge on Traditional Health Care in Ethiopia. In: Zewdu M, Demissie A, editors Conservation and Sustainable use of Medicinal Plants in Ethiopia, Proceeding of the National Workshop on Biodiversity Conservation and Sustainable use of Medicinal Plants in Ethiopia, 28 April-01 May 1998. Addis Ababa: IBCR; 2001. p. 168-75

15. Pankhrust R. The Characteristics of Traditional Ethiopian Medicine and its Traditional Pharmacopoeia. In: Urga K, Asefa A, Guta M, editors. Traditional Medicine in Ethiopia, Proceedings of A National Workshop Held in Addis Ababa, Ethiopia, on June 30-2July, 2003. Addis Ababa: EHNRI; 2004. p. 26-9.

16. Hawkins B. Plants for Life: Medicinal Plant Conservation and Botanic Gardens. Richmond, UK: Botanic Gardens Conservation International; 2008.
17. Getahun A. Some Common Medicinal and Poisonous Plants Used in Ethiopia Folk Medicine. Ethiopia: Addis Ababa University; 1974.

18. HSDP. Health Sector Development Program (HSDP) Annual Plan, Ministry of Health $(\mathrm{MOH})$ of Federal Democratic Republic of Ethiopia. Ethiopia: MOH; 2002.

19. Abbink J. Medicinal and ritual plants for the Ethiopian southwest. An account of recent research. Indigenous Knowledge and Development Monitor. 1995;3(2):6-8.

20. WHO. World Health Organization-Strategy for Traditional Medicine 2000-2003. Geneva: WHO publication; 2000.

21. Abebe D. The role of Medicinal Plants in Health Care Coverage of Ethiopia, the Possible Integration. In: Zewdu M, Demissie A, editors. Conservation and Sustainable use of Medicinal Plants in Ethiopia, Proceedings of the National Workshop on Biodiversity Conservation and Sustainable use of Medicinal Plants in Ethiopia. Addis Ababa: IBCR; 2001. p. 6-21.

22. Fassil $\mathrm{H}$. Ethiopia: a qualitative understanding of local traditional knowledge and medicinal plant use. In IK Notes. 2003;52:1-4.

23. Regassa F. The Role of Traditional Medicine in Animal Healthcare. In: Urga K Assefa A, Guta M, editors. Traditional Medicine in Ethiopia, Proceedings of Anational Workshop Held in Addis Ababa, Ethiopia, on June 30-2July, 2003. Addis Ababa, Ethiopia: EHNRI; 2004. p. 53-8.

24. AWAO. Ada'a Woreda Agricaltural Organization:UnpublishedAnnual Report on Socio- economy of Ada'a District, Ada. 2009.

25. Cunningham AB. Applied Ethnobotany: People, Wild plants and Use and Conservation. London: Eartscan Publisher Limited; 2001.

26. Wassie A. Ethiopian Orthodox Church Forests: Opportunities and Challenges for Restoration. India: Vdm Verlag; 2008.

27. EMA. National Atlas of Ethiopia. Addis Ababa, Ethiopia: Ethiopian Mapping Authority (EMA); 1988.

28. Heinrich M, Ankli A, Frei B, Weimann C, Sticher O. Medicinal plants in Mexico: Healers consensus and cultural importance. Soc Sci Med. 1998;47:1859-71.

29. Schlage C, Mabula C, Mahunnah RLA, Heinrich M. Medicinal plants of the Washamba (Tanzania): documentation and ethnopharmacological evaluation. Plant Biol. 2000;2:83-92.

30. Ankli A, Sticher O, Heinrich M. Medical ethnobotany of the Yucatec Maya: healers' consensus as a quantitative criterion. Econ Bot. 1999;53:144-60.

31. Friedman J, Yaniv AD, Dalewitch D. A preliminary classification of the healing potential of medicinal plants. J Ethnopharmacol. 1986;16:275-87.

32. Kassa Z. An Ethnobotanical Study of Medicinal Plants and Biodiversity of Trees and Shrubs in Jeldu District, Western Shewa, Ethiopia, M.sc thesis. Addis Ababa: Addis Ababa University; 2009.

33. Belayneh A, Bussa NF. Ethnobotanical plants used to treat human ailments in the prehistoric place of Harla and Dengego valleys, eastern Ethiopia. J Ethnobiol Ethnomed. 2014;10:18.

34. Megersa M, Asfaw Z, Kelbessa E, Beyene A, Woldeab B. An ethnobotanical study of medicinal plants in Wayu Tuka District, east Welega Zone of Oromia Regional State, west Ethiopia. J Ethnobiol Ethnomed. 2013:9:68.

35. Lulekal E, Asfaw Z, Kelbessa E, Van Damme P. Ethnoveternary plants of Ankober District, North Shewa Zone, Amhara region, Ethiopia. J Ethnobiol Ethnomed. 2013;9:63

36. Hedberg I, Edwards S. Flora of Ethiopia, Vol. 3, Pittosporaceae to Araliacae. Addis Ababa \& Uppsala: The National Herbarium, Addis Ababa University; 1989.

37. Giday M, Teklehaymanot T. Ethnobotanical study of plants used in management of livestock health problems by Afar people of Ada'ar District, Afar Regional State, Ethiopia. J Ethnobiol Ethnomed. 2013;9:8.

38. Lulekal E, Kelbessa E, Bekele T, Yineger H. An ethnobotanical study of medicinal plants in Mana Angetu district, southeast Ethiopia. J Ethnobiol Ethnomed. 2008:4:10.

39. Bekalo T, Demissew S, Asfaw Z. An ethnobotanical study of medicinal plants used by local people in the lowlands of Konta Special Wereda, southern nations, nationalities and peoples regional state, Ethiopia. J Ethnobiol Ethnomed. 2009;5:26

40. Balemie K, Kelbessa E, Asfaw Z. Indigenous medicinal plants utilization, management and threats in Fentale area, Eastern Showa, Ethiopia. Ethiop J Sci. 2014;3(1):37-58.

41. Friis I, Demissew S, Breugel PV. Atlas of the Potential Vegetation of Ethiopia. Ethiopia: Addis Ababa University Press; 2011

42. Yineger $\mathrm{H}$, Yewhalaw D. Traditional medicinal plant knowledge and use by local healers in Sekoru District, Jimma Zone, South Western Ethiopia. J Ethnobiol Ethnomed. 2007;3:24. 
43. Lulekal E, Asfaw Z, Kelbessa E, Van Damme P. Ethnomedicinal study of plants used for human ailments in Ankober District, North Shewa Zone, Amhara region, Ethiopia. J Ethnobiol Ethnomed. 2013;9:63.

44. Giday M. An ethnobotanical study of medicinal plants used by the Zay people in Ethiopia. CBK: Skriftseries. 2001;3:81-99.

45. Mesfin F, Demissew S, Teklehymanot T. An ethnobotanical study of medicinal plants in Wonago wereda, SNNPR, Ethiopia. J Ethnobiol Ethnomed. 2009:5:28.

46. Ragunathan M, Abey SM. Ethenomedicinal survey of folk drugs used in Bahirdar-Zuria district, Northwestern Ethiopia. Indian J Tradit Knowl. 2007:8(2):281-4.

47. Mesfin K, Tekle G, Tesfay T. Ethnobotanical study of traditional medicinal plants by indigenou people of Gemad District, Northern Ethiopia. J Med Plants Studies. 2013;1(4):32-7.

48. Teklay A, Abera B, Giday M. An ethnobotanical study of medicinal plants in Kilte Awulaelo District, Tigray Region of Ethiopia. J Ethnobiol Ethnomed. 2013:9:65.

49. Belayneh A, Asfaw Z, Demissew S, Bussa NF. Medicinal plants potential and use by pastoral and agro-pastoral communities in Erer valley of Babile Woreda, eastern Ethiopia. J Ethnobiol Ethnomed. 2012;8:42.

50. Flatie T, Gedif T, Asres K, Gebremariam T. Ethnobotanical survey of Berta ethnic group Assosa Zone, Benishangul Gumuz regional state, Mid-west Ethiopia. J Ethnobiol Ethnomed. 2009;5:14.

51. Teklehaymanot T, Giday M. Ethnobotanical study of medicinal plants used by people in Zegie Penisula, NorthwesternEthiopia. J Ethnobiol Ethnomed. 2007:3:12.

52. Teklehaymanot T. Ethnobotanical study of knowledge and medicinal plants use by the people in Dek Island in Ethiopia. J Ethnopharmacol. 2009;124(1):69-78.

53. Giday M, Asfaw Z, Woldu Z. Ethnomedicinal study of plants used by Sheko ethnic group of Ethiopia. J Ethnopharmacol. 2010;132:75-85.

54. Hutching A, Terblanche SE. Observation on the use of some known and suspected toxic liliiflorae in Zulu and Xhosa medicine. SAML. 1989:75:62-9.

55. Johns T, Mhoro PEB, Sanaya EK. Herbal remedies of the Batemi of Ngorongoro District, Tanzania - a quantitative appraisal. Econ Bot. 1994;48(1):90-5

56. Johnson LM. Gitksan medicinal plants-cultural choice and efficacy. J Ethnobiol Ethnomed. 2006;2:29

57. Lewu FB, Afolayan AJ. Ethnomedicine in South Africa: the role of weedy species. Afr J Biotechnol. 2009;8(6):929-34.

58. Kalra YP. Handbook of Reference Methods for Plant Analysis. New York: Soil and Plant analysis Council, Inc., CRC press; 1998.

59. Ehrenpreis S, Ehrenpreis ED. Clinician's Handbook of Prescription Drugs. Chicago: McGraw-Hill, Medical publishing Division; 2001.

60. Vivero JL, Kelbessa E, Demissew S. The Red Lists of Endemic Trees and Shrubs of Ethiopia and Eritrea. Published by Fauna and Flora International (FFI), Cambridge, UK; 2005

61. Hedberg I, Edwards S, Nemomissa S. Flora of Ethiopia and Eritrea. Vol4 (2), Apiaceae to Dipsaceae. The National Herbarium, Addis Ababa University Addis Ababa \& Uppsala; 2003.

62. Hedberg I, Kelbessa E, Edwards S, Demissew S, Persson E. Flora of Ethiopia and Eritrea. Vol 5, Gentianaceae to Cyclocheilaceae. Addis Ababa and Uppsala: The National Herbarium, Addis Ababa University; 2006.

63. Edwards S, Tadesse M, Demissew S. Flora of Ethiopia and Eritrea, Vol. 2 (1), Magnoliaceae to Flacourtiaceae. Addis Ababa \& Uppsala: The National Herbarium, Addis Ababa University; 2000.

\section{Submit your next manuscript to BioMed Central and take full advantage of:}

- Convenient online submission

- Thorough peer review

- No space constraints or color figure charges

- Immediate publication on acceptance

- Inclusion in PubMed, CAS, Scopus and Google Scholar

- Research which is freely available for redistribution 